1 Review

\title{
2 Omega-3 PUFA metabolism and brain modifications during aging
}

3 Laurie Chevalier*, Hillary Chappus-McCendie*, Claude Roberge and Mélanie Plourde ${ }^{1, \#}$

$4 \quad 1$ Research Center on Aging, Health and Social Services Centre - University Institute of Geriatrics of 5 Sherbrooke, Department of medicine, Université de Sherbrooke, 1036 Belvédère Sud, Sherbrooke, 6 Canada, J1H 4C4; E-Mails: Melanie.plourde2@usherbrooke.ca (M.P);

$7 \quad *$ LC and HCM equally contributed to the redaction and the revision of the manuscript and are considered 8 co-first authors.

$9 \quad$ \#Author to whom correspondence should be addressed;

10 E-Mail: Melanie.plourde2@usherbrooke.ca

11 Phone number: +1-819-780-2220 extension 45664;

12 Fax: +1-819-829-7141. 


\section{Abstract:}

15 In Canada, 5.5 million (16\% of Canadians) adults are $>65$ years old and projections suggest this number will be approximately $20 \%$ of Canadians by 2024 . A major concern regarding old age is a

9 0 decline in health, especially if this entails a loss of self-sufficiency and independence caused by a decline in cognition. The brain contains $60 \%$ of fat and is one of the most concentrated organs in long chain omega-3 fatty acids such as docosahexaenoic acid (DHA). During aging, there are physiological modifications in the metabolism of lipids that could also have consequences on brain structure and levels of DHA. This review will hence discuss the physiological modifications in the metabolism of lipids during aging with a focus on long chain omega- 3 and omega- 6 fatty acids and also outline the structural and functional modifications of the brain during aging including brain lipid modifications and its relation to higher levels of DHA and cognition. Therefore, in this review, we outline the importance of collecting more data on the biology of aging since it might highly improve our understanding about what are «normal» modifications occurring during aging and what can become pathological.

Keywords: lipid metabolism, aging, docosahexaenoic acid, fatty acids, brain structure, brain function, 
33

\section{Introduction}

Almost every country in the world experiences an aging population, and this population is expected to be one of the most significant forces shaping our economy and society in the next 20-30 years. A major concern about old age, both at the individual and societal levels, is a decline in health, especially if this means a loss of self-sufficiency and independence. Increasing research aimed at promoting healthy aging is actually ongoing but one of the major hurdles is to define the biology of aging. Aging in humans refers to a multidimensional process of physical, psychological, and social changes. Therefore, it follows that fundamental knowledge on the biological processes occurring during aging may help to design environmental strategies aimed at promoting healthy biological aging. Thus, there is a need for better prevention strategies, but one major gap in this field is a need to better understand what the biological modifications are, also called geroscience, since this field is relatively new. One of the strategies to promote healthy aging is the consumption of one or two fish meals each week ${ }^{1-3}$. Normally, the intake of fish positively correlates with increased plasma and erythrocyte omega-3 fatty acids (n-3 FA), likely with eicosapentaenoic acid (EPA) and docosahexaenoic acid (DHA) concentrations in a time- and dosedependent manner ${ }^{4-6}$. EPA and DHA have to be provided through the diet because their synthesis from their precursor alpha-linolenic acid (ALA) is extremely limited in humans ${ }^{7}$. However, over the $20^{\text {th }}$ century, the dietary fat consumption has drastically changed with an increased level of omega- 6 fatty acids such as linoleic acid (LA) from $2.79 \%$ to $7.21 \%$ of energy. This shift in our dietary fat intake was largely due to our dependence on new food production methodologies, including soybean oil ${ }^{8}$.

The link between our dietary fat intake and the incidence of chronic diseases has been largely debated over the last 20 years. Our research group is mainly focused on prevention of cognitive decline, so the focus of this review paper, with respect to chronic diseases, will be on cognition. This link between dietary fat intake and the risk of cognitive decline has been the focus of many review papers overs the last 10-15 years ${ }^{9-11}$. One of the most recent reviews supports a positive association between dietary and blood n-6: n-3 ratio and cognitive decline and incidence of dementia, as evaluated on 14 human studies including 7 prospective studies ${ }^{12}$. A recent meta-analysis on 11 cohort studies evaluated the association between 299 metabolites and general cognitive ability and dementia. They reported that higher DHA levels in blood were associated with higher cognitive function in 22,887 individuals ${ }^{13}$. Hence, it seems that more elevated concentration of n-3 FA in the blood is associated with lower cognitive decline and perhaps lower risk of other chronic diseases. However, our group showed that for older participants, plasma EPA and DHA kinetics are dysregulated and this will likely lower the capacity of older adults to incorporate EPA and DHA in organs 
64

and tissues. Usually, a fish oil supplementation increases the level of EPA and DHA in the plasma or erythrocytes but in those aged $>70$ years old, we don't know whether this process is efficient. There is no clear definition or parameters to define an old $v s$. a young participant. Most of the studies used the median of age in their participants group or a continuous age ae range. Following from the information summarized above, this paper will review some of the metabolism modifications occurring during aging with a focus on lipid metabolism. By reviewing these evidences, we will also expose how these modifications might limit incorporations of n-3 FA in membranes of cells with a focus on the brain because it is one of the most enriched organs in DHA.

\section{Lipid and fatty acid metabolism differences during aging}

Generally speaking, there are differences in the lipid and fatty acid metabolism occurring during aging and these modifications are considered totally normal and part of the aging process. These processes include the transport of fatty acids after their intake and their transit to the different organs and tissues that are modified during aging. This section will review some of these modifications.

\subsection{Normal transport of fatty acids from dietary intake to their circulation in the blood:}

In Western adults, the diet is composed of 30 to $40 \%$ of lipids, of which 92 to $96 \%$ are long chain fatty acid esterified to a glycerol thus constituting what is the main form of dietary lipid: triglycerides (TG) ${ }^{14}$. Whole-body homeostasis requires fine-tuning of fatty acid transport and utilization by metabolically active tissues ${ }^{15}$. Because of their regulatory roles in cellular fatty acid uptake and utilization, membrane apolipoprotein receptors and fatty acid transporters form an integral part of this homeostatic system. As a result, imbalances in lipid metabolism likely will influence the functioning of fatty acid transporters and their protein levels. Lipids are not soluble in water and necessitate incorporation into amphiphilic molecules called lipoproteins to circulate in the blood. Hence, following ingestion of TG, they will be hydrolysed at their ester bonds by gastric and pancreatic lipases into two non-esterified fatty acids (NEFA) and one monoacylglycerol (MAG) with the fatty acid being in the $S n-2$ position ${ }^{16}$. Both forms of lipids are passively transported into enterocytes ${ }^{17}$ via diffusion or transporters such as "Fatty Acid Transport Proteins" (FATPs) and "Cluster of Differentiation 36" (CD36) ${ }^{18}$. Dietary lipids are efficiently digested and absorbed by the enterocytes 19 .

Once inside the intestinal cells, enzymes convert the NEFAs and MAG back into TG ${ }^{20}$. These will be integrated in chylomicrons and exported to the lymphatic system via the Golgi apparatus ${ }^{21}$. 
The chylomicrons, now rich in exogenous triglycerides, join the bloodstream via the thoracic duct and get transported to the peripheral tissues such as muscle and fat cells. In the bloodstream, lipoprotein lipase (LPL) gets activated when it detects an apolipoprotein C II (apoC-II) ${ }^{22}$ on the surface of the chylomicrons. The role of lipoprotein lipase is to hydrolyse the ester bonds of TGs in chylomicrons ${ }^{22}$ to release NEFAs into the bloodstream where there will be an uptake by nearby cells. The loss of TGs will result in a decrease in size of chylomicrons and leave chylomicrons constituents available for the synthesis of native HDL disks ${ }^{23}$. Remnant chylomicrons rich in cholesteryl esters will be captured by endocytosis by hepatocytes receptors such as LDL receptor (LDLR) ${ }^{22}$ and LDL receptor-related protein (https://onlinelibrary-wileycom.ezproxy.usherbrooke.ca/doi/abs/10.1002/\%28SICI\%2910969136\%28199708\%2914\%3A3\%2B\%3CS75\%3A\%3AAID-DIA449\%3E3.0.CO\%3B2-9). The liver can then use the endogenous TG and cholesteryl esters to form the very low density lipoprotein (VLDL) ${ }^{24}$. These lipoproteins will be directed to peripheral tissues. Following a loss of TG, there will be a decrease in VLDL density ${ }^{25}$. With the action of lipoprotein lipase, VLDL will then become intermediate density lipoprotein (IDL). With the action of hepatic lipase ${ }^{25}$ IDL becomes low density lipoprotein (LDL). LDLs carry cholesterol to tissues ${ }^{26}$. LDL will be captured by their receptor, LDLR which are found on cell membranes, where it will be eliminated from the bloodstream by endocytosis ${ }^{26}$. LDL cholesterol will be recovered in the cell. An excess of cholesterol in the tissues will cause an inhibition of transcription of the genes responsible for the formation of the LDLR ${ }^{27}$. It thus reduces the uptake of LDL by the cells and these LDLs will remain in circulation. The remaining LDLs in the circulation are more likely to be oxidized ${ }^{28}$ which will thereafter contribute to the development of atherosclerotic plaque ${ }^{28}$.

\subsection{Lipoprotein metabolism modification during aging}

During aging, the metabolism of lipids is modified and causes an increase of plasma lipids. For instance, the fasting plasma levels of VLDL, TG, LDL and cholesterol ${ }^{29}$ are significantly higher in the elderly ${ }^{30}$. Higher levels of lipid and cholesterol can be the source of many health problems such as cardiovascular disease and diabetes (REF =http://diabetes.diabetesjournals.org/content/46/8/1354.full-text.pdf + https://www.ncbi.nlm.nih.gov/pmc/articles/PMC4587882/).

These plasma lipid changes in the elderly can cause an increase in plasma free fatty acid levels (https:/edsb-ebscohost-com.ezproxy.usherbrooke.ca/eds/pdfviewer/pdfviewer?vid=1\&sid=3f462f39-8acd-4cbf- 
124 b113-b378e62a44c1\%40sessionmgr103). Increasing plasma FFA may result in increased plasma glucose 125 by decreasing glucose uptake into the cells. The enzymes responsible for the oxidative cascade of GLA are 126 intimately related to that of glycolysis. Thus, increased lipid oxidation inhibits glucose metabolism, 127 decreases glucose uptake in cells, and impairs glycogen storage 128 http://diabetes.diabetesjournals.org/content/diabetes/37/6/667.full.pdf.. This promotes hyperinsulinemia 129 and ultimate insulin https://eds-b-ebscohost130 com.ezproxy.usherbrooke.ca/eds/pdfviewer/pdfviewer?vid=1\&sid=3f462f39-8acd-4cbf-b113131 b378e62a44c1\%40sessionmgr103.

132 Insulin resistance, often seen in the elderly (https://www.jci.org/articles/view/110908/pdf), will also cause 133 an increase in VLDL and blood triglycerides. Insulin resistance impairs the metabolism of chylomicrons, VLDL, LDL and HDL ${ }^{31}$ since a lack of insulin or a lower sensitivity to insulin will reduce the catabolism of chylomicrons and VLDL by LPL. During aging, there is also a higher level of LDL which remains transient for a longer period of time in the plasma (Einarsson K, Nilsell K, Leijd B, Angelin B. Influence of age on secretion of cholesterol and synthesis of bile acids by the liver. N Engl J Med 1985;313(5):277-82. doi: 10.1056/NEJM198508013130501.) as a reference of this statement. = REF 30). In the long term, these LDLs are more likely to be oxidized ${ }^{31}$. The higher concentration of VLDL and chylomicrons in addition to oxidized LDL accumulation in older insulin-resistant individuals would increase the risk of developing cardiovascular disease (CVD) ${ }^{32}$. Furthermore, the increase of LDL may be due to the diminution of bile synthesis from cholesterol by the liver during aging ${ }^{30,33}$. The decrease in bile acid synthesis is due to the decrease in the expression of "cholesterol 7-alpha hydroxylase" (CYP7A1) during aging. This cytochrome is one of the CYP450 and regulates the formation of bile acids ${ }^{34}$. This causes a decrease in the use of cholesterol by the liver as well as a reduction in LDLR expression with age. Thus, plasma LDL will have lower clearance with age resulting in an increase in plasma LDL concentration in the elderly ${ }^{29}$. In the end, it is possible that deregulation of LDL in the elderly is due to several different phenomena stemming from the large amount of change that occurs with age. The decrease in LDL in the elderly has shown a reduction in the incidence of CVD ${ }^{35}$. In particular, a study showed that long chain polyunsaturated fatty acids (PUFAs) allowed an increase in LDLR expression ${ }^{36}$, which could increase the clearance rate of plasma LDL in the elderly and reduce the incidence of CVD. These are some of the modification of the lipid metabolism occurring during aging. Overall, there are usually higher TG and LDL levels in the blood of older adults and it is important to consider these modifications in the prevention of chronic diseases but also 
155

156

157

158

159

160

161

162

163

164

165

166

167

168

169

170

171

172

173

174

175

176

177

178

179

180

181

182

183

184

\subsection{Omega-3 fatty acid metabolism during aging}

Over the last 10 years, our group has worked on omega-3 metabolism with a focus on modifications that occur during aging. This section will report the evidence of omega-3 fatty acid metabolism in three different conditions: before supplementation with omega-3, during or after supplementation with omega-3 fatty acid, and kinetics studies using uniformly labeled carbon 13 fatty acids $\left({ }^{13} \mathrm{C}-\right)$.

\subsubsection{Without an omega-3 fatty acid supplementation}

To our knowledge, there are $\sim 24$ studies that have reported the level of omega- 3 fatty acids or the omega-3 index in young versus old adults (Table 1). Most of the studies reported the fatty acid profile in red blood cells or in plasma/serum phospholipids (PL). Among the 24 studies, 7 studies reported the omega-3 index only and showed that it was higher in older participants ${ }^{37-43}$. Two studies on the omega-3 index reported an increase of about 5-7\% of the omega-3 index every decade ${ }^{37,41}$. Eleven studies reported the fatty acid profile in red blood cells (RBC) $37,38,41-50$. For most of the studies, it is difficult to compare the results since the data were not expressed the same way. For instance, two studies reported that the participants having the highest level of omega-3 were on average 8-10 years older than those with the lowest omega-3 fatty acid levels in erythrocytes ${ }^{43,44}$. Other studies reported the level of increase in omega-3 fatty acids for each increasing decade. Hence, it is difficult to draw a clear conclusion for the omega-3 fatty acid results in RBC but it appears that at older ages, there is more omega-3 in RBC. It is important to note that these papers did not include a complete fatty acid profile of the RBC as it was recently recommended in a paper describing the best practices for the design, laboratory analysis and reporting of clinical trials involving fatty acids ${ }^{51}$, hence limiting comparisons between studies. With respect to plasma/serum PL, there were eight studies ${ }^{45,52-58}$. Six of these studies reported on average a 1.5 fold higher level of DHA in the plasma PL of older participants, aged between 50-88 years old compared with younger participants, aged between 20-49 years old ${ }^{45,53-57}$. One study reported a 2 fold higher level of EPA in plasma PL but there were no difference between ages for DHA ${ }^{52}$. Yet another study reported only a positive correlation between age and EPA+DHA in plasma PL but it was not possible to quantify the magnitude of the difference between young and older adults ${ }^{58}$. Overall, there is generally good evidence supporting the idea that during aging, the relative \% of omega-3 fatty acids or its concentration in RBC and plasma/serum are 
185

186

187

188

189

190

191

192

193

194

195

196

197

198

199

200

201

202

203

204

205

206

207

208

209

210

211

212

213

214

215

higher in the oldest participants compared to the youngest. Some of the proposed mechanism includes a reduction of omega-3 fatty acids in cell membranes, higher intestinal absorption during aging, higher availability and release of adipose tissue stocks. Hence, the exact mechanism behind this higher level of blood omega-3 in older individuals might be multi-level but the important point here is that they might be associated to longevity.

\subsubsection{With an omega-3 fatty acid supplementation}

To our knowledge, there are nine published studies specifically addressing EPA and DHA responses to an omega-3 fatty acid supplement with participants of different ages (Table 2). Supplementation doses range from $300 \mathrm{mg} / \mathrm{d}$ to more than $4 \mathrm{~g} / \mathrm{d}$ and lasted between 6 weeks and twelve months. Seven studies evaluated the fatty acid profile in the plasma whereas one study evaluated the fatty acid profile in erythrocytes only ${ }^{59}$ and another did so in platelets and adipose tissues only ${ }^{60}$. One study reported the omega- 3 index pre- and post-supplementation ${ }^{59}$ and showed that a low omega-3 index at baseline and an older age predicted those with a greater increase of the omega-3 index after supplementation ${ }^{59}$. This study had similar results to Vandal et al., ${ }^{61}$ which showed that the oldest had a higher increase in DHA compared to the youngest after the supplementation, but in their study, Vandal had similar DHA levels in young and old participants at baseline.

The other studies investigated the plasma level of omega-3 fatty acids. One study reported that older participants had higher omega-3 levels at baseline but after the supplementation, the increase was similar in both groups ${ }^{62}$. The six other studies reported a higher increase in EPA ${ }^{63-67}$ and/or DHA ${ }^{68}$ in older participants compared to younger. The exact mechanism explaining this effect is unclear. Most of the studies reported that it is unlikely that the age-related differences in EPA and DHA at baseline are due to differences in intake of omega-3 PUFA with age. Rather it seems to be related to age differences in endogenous production and incorporation of EPA and DHA due to hormones and hormone sensitivity, body composition, and physical activity, all of which change with age ${ }^{67}$. The study of Walker et al. also showed that the adipose tissue stores less DHA with age in response to EPA + DHA supplementation, hence suggesting that age-related differences in the handling and storage of exogenous supplied DHA may be related to impaired insulin sensitivity with aging or to differences in body composition with aging ${ }^{67}$. The adipose tissue represents a significant store of EPA and DHA, containing the equivalent of several hundred days of the fatty acid content of a typical diet. Altogether, these results support that providing a supplement of omega-3 fatty acid to older adults increases their blood levels when compared to younger individuals. 
than younger people (REF $=$ https://onlinelibrary.wiley.com/doi/full/10.1046/j.1365-2710.2000.00315.x), causing a higher level of omega-3 in their blood. But despite that fact, those results brings into question whether this type of supplementation is useful to them in the prevention of chronic diseases since they may not be able to use it. Another important point is that it might also be due to their lower turnover of circulating TG, hence contributing to their higher omega-3 levels, since omega-3 fatty acid levels are esterified in TG. To answer some of these questions, employing ${ }^{13} \mathrm{C}$-fatty acids is useful.

\subsubsection{Using ${ }^{13} \mathrm{C}$-fatty acid to evaluate their kinetics during aging}

Tracing metabolism of ${ }^{13} \mathrm{C}$-fatty acids may provide some insight into possible age-related changes in fatty acid metabolism in humans. Metabolism of ${ }^{13} \mathrm{C}$-DHA has been investigated in humans ${ }^{69-71}$. In young adults given an oral dose of $250-280 \mathrm{mg}{ }^{13} \mathrm{C}$-DHA, ${ }^{13} \mathrm{C}$ enrichment peaked at $2 \mathrm{~h}$ post-dose in plasma triglycerides when the tracer was given in the triglyceride form, but at $6 \mathrm{~h}$ post-dose when the tracer was esterified to phosphatidylcholine ${ }^{69,71}$. Brossard et al. have reported a $1.4 \%$ apparent retroconversion of ${ }^{13} \mathrm{C}$-DHA to ${ }^{13} \mathrm{C}$-docosapentaenoate (22:5 omega-3) and ${ }^{13} \mathrm{C}$-EPA $3 \mathrm{~d}$ after giving the $\operatorname{tracer}^{70}$. These first results showed the feasibility of tracing DHA metabolism in humans. However, neither the impact of aging on ${ }^{13} \mathrm{C}$-DHA metabolism nor its $\beta$-oxidation were investigated, although both may influence the somewhat higher blood levels of EPA and DHA commonly seen in healthy elderly ${ }^{54,65,66,68,72}$. Our group are pioneers in this field as we investigated the kinetics of ${ }^{13} \mathrm{C}$-DHA in six young and six elderly participants ${ }^{73}$. We found that, in the elderly, ${ }^{13} \mathrm{C}$-DHA was 4 times higher in plasma triglycerides and NEFA at $4 \mathrm{~h}$ post-dose, $\beta$-oxidation was 1.9 times higher, whereas apparent retro-conversion of ${ }^{13} \mathrm{C}$-DHA to other ${ }^{13} \mathrm{C}$-omega-3 fatty acids was 2.1 times higher $24 \mathrm{~h}$ and $7 \mathrm{~d}$ after tracer intake compared to the young adults ${ }^{73}$. Hence, because DHA seems to remain transiently for longer periods of time in the blood of the elderly compared to the young, it may thus indicate that efficiency to remove DHA from the blood is lower in the elderly than in the young, resulting in lower incorporation of DHA in the membrane of cells that serve to initiate signalization $65,66,68,72$. This result is consistent with the transient slower metabolism of TG and LDL in older as compared to young adults and this was described in a previous section.

Our most recent work with tracers between old and young men was conducted with ${ }^{13} \mathrm{C}$-EPA or arachidonic acid $\left({ }^{13} \mathrm{C}\right.$-ARA), two key fatty acids that are precursors of anti- and pro-inflammatory cytokines, respectively. Surprisingly, the kinetics of ${ }^{13} \mathrm{C}$-EPA and ${ }^{13} \mathrm{C}$-ARA was quite similar between young and old men despite a time $\mathrm{x}$ age interaction for ${ }^{13} \mathrm{C}$-EPA kinetics where the postprandial shape 
246 of the curve was steeper in old vs young men ${ }^{74}$. One intriguing result we obtained was that in old 247 men, synthesis of DHA from EPA started $2 \mathrm{~h}$ after tracer intake whereas it was delayed to $1 \mathrm{~d}$ in young men. This result suggests that old adults might need more DHA than what was actually provided in their diet compared to the young men. However, newly synthesized DHA accumulated in the plasma of old men for $7 \mathrm{~d}$ and this might be because it remains for a longer period in the plasma as suggested by our previous study with ${ }^{13} \mathrm{C}$-DHA. Therefore, there might be a defect in old adults to uptake DHA in the tissues. We also calculated that plasma half-life of ${ }^{13} \mathrm{C}$-EPA was $2 \mathrm{~d}$ whereas that of ${ }^{13} \mathrm{C}$-ARA was $4 \mathrm{~d}$, similar to that of DHA. DHA and ARA are the two most concentrated long chain polyunsaturated fatty acids in brain membranes. With our $\beta$-oxidation measures using breath samples, we calculated ${ }^{13} \mathrm{C}$-EPA whole-body half-life to be $\sim 14$ days in old men whereas in the younger group it was $\sim 21$ days ${ }^{74}$. This result indicates that older adults turn over EPA $\sim 7$ days faster than the younger adults. This is an intriguing result since epidemiological studies and results we obtained in previous studies ${ }^{62,65}$ support that old adults have twice as much plasma EPA, hence one would anticipate a lower whole-body turnover in old vs young adults. Therefore, it seems that there is somehow a disconnect between plasma levels of EPA and perhaps DHA and their kinetics, thus more studies are needed to understand the mechanism of these modifications and their possible consequences such as potential higher risk of cognitive decline.

\section{Brain modifications during aging:}

The brain is composed of $60 \%$ fat with one third of its content being ARA and DHA. The brain is hence the second most rich tissue in fat after adipose tissue. The brain fatty acids are however mostly PLs unlike the adipose tissue that is mainly composed of TGs. Because DHA is an important constituent of brain structure, there has been much interest in the association between the level of DHA in brain membranes, brain function and brain volume and losses during aging. Therefore, this section will summarize the evidence about morphological, functional, and content modifications of the brain during aging and whether dietary omega-3 intake can improve brain structure and function.

\subsection{Morphological modifications of the brain during aging}

There are a number of morphological modifications of the brain that occur during aging. Several studies have indicated that brain volume decreases over the course of the human lifespan. A review conducted by Hedman et al. ${ }^{75}$ compiled the results of 56 longitudinal magnetic resonance imaging (MRI) studies on whole brain volumes in healthy individuals and concluded that the rate of total brain volume loss 
276

277

278

279

280

281

282

283

284

285

286

287

288

289

290

291

292

293

294

295

296

297

298

299

300

301

302

303

304

is not constant throughout aging. For instance, the rate of brain volume loss after 35 years of age is approximately $0.2 \%$ per year. Between 35 and 60 years of age, the volume loss rate slowly increases to $0.5 \%$ followed by a steady volume loss of over $0.5 \%$ per year over 60 years of age ${ }^{75}$. Furthermore, other studies have indicated that volume loss in the whole brain is greater in males than in females ${ }^{76,77 .}$

Several studies demonstrate a reduction of gray matter volume during aging ${ }^{78-84}$. More specifically, the volume of gray matter in the cortex and the cerebellum of older individuals is $18 \%$ and $13 \%$ smaller, respectively, than those of their younger counterparts ${ }^{81}$. There is also a significant loss of gray matter in the frontal, limbic, temporal, and parietal lobes but not in the occipital lobe ${ }^{78,83}$. Similarly, studies have also indicated that there is a decrease of white matter volume in the brains of older individuals ${ }^{81,85-87}$. According to Jäncke et al. ${ }^{81}$, there is a decrease in white matter volume in the cortex and cerebellum of older individuals by $5 \%$ and $\sim 9 \%$, respectively, compared to younger adults. Moreover, one study indicated that the rate of decrease of white matter is not constant during aging ${ }^{87}$. Instead, white matter volume slowly increases before the age of 40, peaks at approximately 50 years of age, and then quickly decreases after the age of 60 ${ }^{87}$. As well, white matter hyperintensity lesions increase in size with age in the frontal, temporal, and parietal lobes but not in the occipital lobes ${ }^{86}$.

In addition to age-related changes in the volume of the whole brain, gray matter, and white matter, there are also differences in the volume of specific brain structures. There seems to be a general decrease in the volume of the following brain structures in older individuals compared to younger individuals: cerebral hemisphere ${ }^{76}$, frontal lobe ${ }^{88,89}$, parietal lobe ${ }^{77,88,89}$, temporal lobe ${ }^{88,89}$, thalamus ${ }^{81,90}$, basal ganglia ${ }^{89}$, and the cerebellum ${ }^{89}$. Notably, there is atrophy of the hippocampus during aging ${ }^{77,81,91-93}$. A meta-analysis by Fraser et al. ${ }^{93}$ detailed hippocampal atrophy rates according to 28 studies. They determined that the overall rate of atrophy for the entire sample was $0.85 \%$ per year ${ }^{93}$. However, the rate of hippocampal atrophy reported in the studies differed based on mean age of the participants: rate of atrophy was $0.38 \%$ per year in studies with a mean age of $55,0.98 \%$ per year for a mean age of 55 to 70 years, and $1.12 \%$ per year for a mean age of greater than 70 years. In contrast to the aforementioned structures, the ventricles of the brain increase in volume during aging ${ }^{76,91}$. Altogether, there is generally good evidence supporting loss of matter in many brain structures, including loss in white and gray matter. These losses of brain matter can contribute to lower cognitive functions during aging.

\subsection{Modification of brain functions during aging}


In addition to the many structural changes that occur during aging, brain functions are also modified during this period. For instance, there is an age-related decrease in glucose metabolism in the whole brain and the frontal, parietal, and temporal lobes as well as in Broca's and Wernicke's areas ${ }^{77}$. It also seems that brain activation during the execution of motor functions is modified in older adults. For example, there is a decrease in blood-oxygen level dependent (BOLD) signals in multiple brain regions (sensorimotor cortex, cerebellum and thalamus) of older adults during mastication and an increase in BOLD signal in the prefrontal area ${ }^{94}$. Another study showed that classical motor coordination regions were activated during complex inter-limb coordination tasks, but that there was also increased activation of higher-level sensorimotor and frontal regions in older individuals ${ }^{95}$. Similarly, other studies have demonstrated that the performance of motor tasks result in increased activation of additional brain areas such as the basal ganglia, prefrontal cortex, precuneus, and the cerebellum ${ }^{96-98}$ in older invividuals.

Moreover, cognitive functions are modified as a result of changes in the volume of various brain structures. For instance, a meta-analysis of 57 publications from the years 1984 to 1998 concluded that white matter hyperintensities are linked with poorer performance on cognitive tests for processing speed, immediate and delayed memory, executive functions, and global cognitive functioning ${ }^{99}$. Further, a decrease in the thalamus volume in older individuals is associated with attenuated performance on tests assessing cognitive speed ${ }^{90}$. An additional meta-analysis of 33 studies concluded that larger prefrontal cortex volume and thickness is correlated with better executive functioning ${ }^{100}$. In regard to hippocampus volume and memory, Van Petten ${ }^{101}$ reported in a meta-analysis of 33 studies that the positive correlation between hippocampus size and episodic memory in older adults was weaker than expected. However, a more recent study demonstrated that smaller hippocampus size is significantly associated with lower performance in episodic memory, working memory, processing speed, and executive function tasks ${ }^{102}$. Similarly to motor function, it has been shown that older adults recruit additional brain regions during memory tasks ${ }^{103-105}$.

Aging is also associated with changes in the activity of brain structures involved in sensation and perception. For instance, there are less areas activated in older versus younger adults in response to various odors ${ }^{106}$. A meta-analysis of 105 studies concluded that the activation of the fusiform gyrus, cerebellum, and hippocampus is elevated in elderly versus younger individuals during the processing of emotional faces ${ }^{107}$. Moreover, older individuals had greater activation of the prefrontal cortex during more difficult perceptual tasks compared to younger individuals ${ }^{108}$. The brains of older adults are also less responsive to blue light stimulation compared to younger adults ${ }^{109}$. 
335

More recent studies have shed light on the changes that occur in the functional neural networks of the brain. It seems that aging is associated with weaker connectivity in long-range connections and stronger connectivity of short-range connections ${ }^{110,111}$. Elderly individuals also have less intra-network and greater inter-network connectivity ${ }^{112,113}$. More specifically, older individuals have less connectivity within the default mode network (DMN) and somatomotor network ${ }^{113}$, as well as greater connectivity between the salience network and the executive control network (ECN) and the DMN ${ }^{112}$. Moreover, age seems to shift dynamic functional connectivity from posterior to anterior regions, which is also reflected in the decreased activation of posterior regions during the decline of episodic memory in older individuals ${ }^{114}$.

Overall, there are several morphological and functional modifications within the brain during aging and understanding how these modifications manifest could be helpful to limit the rate at which these declines occur.

\subsection{Modifications of brain content during aging}

The number of studies, particularly those that use neuroimaging techniques, that have evaluated the change in human brain content during aging is limited. Post-mortem examinations of the human brain have indicated that there is a change in protein and lipid content during aging. With regard to protein, one study indicated that there is a $5-15 \%$ decrease in total protein content of the brain between 30 and 90 years of age 115. A decrease in protein content in the substantia nigra, hippocampus, caudate nucleus, and gray matter has also been reported ${ }^{116,117}$. However, Söderberg et al. ${ }^{116}$ found that protein content remained unchanged in the cerebellum, pons, and medulla oblongata of older individuals. Similarly, a number of post-mortem studies have demonstrated changes in the lipid content of older brains. For instance, Svenerholm et al. ${ }^{118}$ reported that there is a linear decrease in cholesterol and phospholipids in the frontal and temporal cortices and a curvilinear decrease in cholesterol, PLs, cerebrosides, and sulfatides in frontal and temporal white matter between the ages of 20 and 100. In terms of PLs, Söderberg et al. ${ }^{116}$ found that they were relatively unchanged during aging with only a $5-10 \%$ decrease in the oldest age group. A more recent study conducted by Hancock et al. ${ }^{119}$ reported that PL content in the entorhinal cortex of older individuals is relatively stable during aging, but there is an increase in mitochondrial phosphatidylcholine (PC) and a decrease in mitochondrial phosphatidylethanolamine (PE). The same group reported that age is associated with an increase in mitochondrial PE containing DHA, but said the increase is not large enough to increase total DHA in the mitochondria. Norris et al. ${ }^{120}$ examined phospholipid composition in the dorsolateral prefrontal cortex in individuals aged 20-100 years. They found that there is a general age-related increase in phospholipids containing DHA and decrease in PLs containing ARA and docosatetraenoic acid ${ }^{120}$. 
366

367

368

369

370

371

372

373

374

375

376

377

378

379

380

381

382

383

384

385

386

387

388

389

390

391

392

393

394

395

396

A recent study used positron emission tomography to assess the incorporation of DHA from plasma to the brain using carbon-11 ([1-C $\left.\left.{ }^{11}\right]\right)$-DHA in apolipoprotein E epsilon 4 allele (APOE4) carriers versus noncarriers ${ }^{121}$. APOE4 is the most important genetic risk of late-onset Alzheimer's disease ${ }^{122}$. Yassine et al. found that the mean global gray matter DHA incorporation coefficient was 16\% higher in APOE4 carriers vs non-carriers ${ }^{121}$. A higher DHA incorporation coefficient was also observed in other regions including the entorhinal cortex ${ }^{121}$. However, the whole-brain DHA incorporation rate was not significantly different between APOE groups ${ }^{121}$. They also did not observe any age-related effects on DHA incorporation, but this may be due to the fact that only 4 of their 23 participants were over 50 years old ${ }^{121}$. The authors hypothesized that increased DHA incorporation in the brains of APOE4 carriers could be a compensatory mechanism to counteract brain DHA loss ${ }^{121}$. Our group also documented that the metabolism of DHA is imbalanced in APOE4 carriers ${ }^{123-126}$ and that they are perhaps more vulnerable to DHA deficiency ${ }^{127}$.

\subsection{Does omega-3 fatty acid consumption improve brain structure and function?}

There are a number of studies that have examined the relationship between omega- 3 fatty acid consumption and brain structure and function. For instance, Gu et al. ${ }^{128}$ evaluated the link between white matter integrity and dietary nutrient intake in 239 elderly participants. They assessed white matter integrity using fractional anisotropy measured by diffusion tensor imaging (DTI). They found that the nutrient pattern characterized by high consumption of omega-3 and omega- 6 fatty acids and vitamin E was positively correlated with fractional anisotropy which corresponds to better white matter integrity ${ }^{128}$. Another group examined the relationship between dietary fish consumption and brain structural integrity in 260 cognitively normal adults aged 65 years or older ${ }^{129}$. Fish intake was measured using the National Cancer Institute Food Frequency Questionnaire and the gray matter volume of various brain regions was measured with MRI ${ }^{129}$. They found that eating baked or broiled fish weekly is positively associated with higher gray matter volume in several brain regions, including the hippocampus, posterior cingulate, precuneus, and the orbital frontal cortex ${ }^{129}$. Samieri and colleagues ${ }^{130}$ evaluated the association between plasma EPA and DHA concentrations and gray matter atrophy in the medial temporal lobe in 281 individuals aged 65 years or older. The authors compared fatty acid plasma concentrations at baseline to the results of MRI examinations from baseline and four years after baseline ${ }^{130}$. They observed that greater levels of plasma EPA was associated with lower atrophy of the gray matter of the right amygdala and the hippocampal/parahippocampal region; this same association was not observed for plasma DHA levels ${ }^{130}$, which is counterintuitive. Samieri et al. ${ }^{130}$ also found that increased amygdala gray matter atrophy was linked with more depressive symptoms and poorer semantic memory performances compared to baseline. Lastly, Witte et al. ${ }^{131}$ assessed the connection 
397

between fish oil supplement consumption and brain structure and function in 65 participants aged 50 to 75 years. Participants consumed either fish oil, which contained 2.2 grams of omega-3 fatty acids, or a placebo daily for 26 weeks. Neuropsychological testing and MRI examinations were performed before and after the intervention period. The investigators found that after the 26-week intervention period, the fish oil group had better white matter structural integrity in selective white matter tracts in the frontal, temporal, parietal, and limbic areas ${ }^{131}$. They also observed that the fish oil group had significant increases in gray matter volume in the left hippocampus, precuneus, the superior temporal, inferior parietal and postcentral gyri, and in the right middle temporal gyrus ${ }^{131}$. In terms of performance on cognitive measures, they found that the fish oil group had an improvement of $26 \%$ on executive function scores compared to no improvement in the placebo group ${ }^{131}$. In addition, they found a positive correlation between verbal fluency scores and EPA percentage in red blood cell membranes in the fish oil group after intervention ${ }^{131}$. Although for many years it was thought that an intake of fish throughout life protects against cognitive decline, the recent evidence suggests that fish intake might not be required throughout life to improve brain structure and function. Hence, starting an EPA+DHA supplementation after 50 years old might benefit older individuals with respect to prevention of brain volume and function losses.

\section{Are we ready for updated recommendations on dietary omega-3 fatty acids intake during aging?} In this review paper, we have outlined that there are many physiological modifications occurring during aging with respect to lipid metabolism and brain volume and function losses and that an omega-3 fatty acid intake might help to support the brain throughout aging. It is important to note that life expectancy is longer, which means that older adults may live longer with their chronic diseases. A major concern regarding old age is a decline in health, especially if this entails a loss of self-sufficiency and independence caused by a decline in cognition. A decline in working memory appears to be one of the major consequences of normal aging ${ }^{132,133}$. As outlined in the previous sections, the brain undergoes physiological change during aging. While age is one risk of cognitive decline, this multifactorial disease is also increased by a complex interaction between both genetic and environmental risk factors ${ }^{134-136}$.

We believe nutrition has a role to play in the prevention of cognitive decline but nutrition alone might not be as efficient as a multidomain intervention. Recent evidence from the FINGER trials ${ }^{137}$ reported that combining physical exercise, personalized nutritional recommendations to avoid nutrient deficiencies, controlling cardiovascular risks and having cognitive stimulation prevented cognitive decline. However, they recently refocus their message by showing that dietary changes initiated early in the intervention was the most influential for global cognition improvement over two years of follow-up 
$428 \quad 138$. Therefore, nutrition might have a key role to play in the prevention of cognitive decline. In the case 429 of the FINGER study, dietary recommendations were not focussed on the consumption of fish oil but 430 were either focused to alleviate nutritional deficiency including low blood levels of DHA. It also has to 431 be emphasized that there is currently no drug to prevent, cure or delay the progression of dementia and 432 that some pharmaceutical companies have shut down their research laboratories in this area. Therefore, 433 prevention strategies are currently the most efficient means since once the disease process has started, 434 there is no available drug for limiting its progression. However, there is one group in Canada working 435 on a nutritional strategy, a ketogenic beverage. They reported that a ketogenic beverage increases brain 436 energy metabolism in Alzheimer's patients ${ }^{139,140 .}$

437 Returning to the question of if we are ready to change recommendations on omega-3 fatty acids, we think 438 that we are not there yet. However, working on the biology of aging might greatly improve our 439 understanding about what are «normal» modifications occurring during aging and what can become 440 pathological. Seizing this opportunity, we might contribute to the prevention of cognitive decline in the 441 future with nutrition playing a vital role in this process. 


\section{Acknowledgements}

445

446

447

448

449

450

451

452

453

454

455

456

457

458

459

460

461

462

463

464

465

466

467

468

469

470

471

472

473

474

475

476

477

478

479

This work was supported by Canadian Institute of Health Research (CIHR, MOP 119454), Quebec Network of research in aging, Natural Science and Engineering Research Council of Canada, Research center on aging for a scholarship to LC, Faculté de Médecine et des sciences de la santé for a scholarship to HCM, and CIHR for a salary award to MP. MP also hold an institutional research chair on lipid metabolism during aging funded by the medical research center of Université de Sherbrooke.

\section{Conflicts of Interest}

MP received funding from Neptune Wellness Solutions but the funding did not funded studies cited in this review and did not funded any of the work of this review.

\section{References}

1. Barberger-Gateau P, Letenneur L, Deschamps V, Peres K, Dartigues JF, Renaud S. Fish, meat, and risk of dementia: cohort study. Bmj. 2002;325(7370):932-3.

2. Holub DJ, Holub BJ. Omega-3 fatty acids from fish oils and cardiovascular disease. Mol Cell Biochem. 2004;263(1-2):217-25.

3. Morris MC, Evans DA, Tangney CC, Bienias JL, Wilson RS. Fish consumption and cognitive decline with age in a large community study. Arch Neurol. 2005;62(12):1849-53.

4. Arterburn LM, Hall EB, Oken H. Distribution, interconversion, and dose response of $n-3$ fatty acids in humans. Am J Clin Nutr. 2006;83(6):S1467-76.

5. Vidgren HM, Agren JJ, Schwab U, Rissanen T, Hanninen O, Uusitupa MI. Incorporation of n-3 fatty acids into plasma lipid fractions, and erythrocyte membranes and platelets during dietary supplementation with fish, fish oil, and docosahexaenoic acid-rich oil among healthy young men. Lipids. 1997;32(7):697-705.

6. Calder PC. Polyunsaturated fatty acids and inflammation. Prostaglandins Leukot Essent Fatty Acids. 2006;75(3):197-202. Epub 2006/07/11.

7. Plourde M, Cunnane SC. Extremely limited synthesis of long chain polyunsaturates in adults: Implications for their dietary essentiality and use as suppements. Appl Physiol Nutr Metab. 2007;32(4):619-34.

8. Blasbalg TL, Hibbeln JR, Ramsden CE, Majchrzak SF, Rawlings RR. Changes in consumption of omega-3 and omega- 6 fatty acids in the United States during the 20th century. The American Journal of Clinical Nutrition. 2011;93(5):950-62.

9. Cunnane SC, Plourde M, Pifferi F, Begin M, Feart C, Barberger-Gateau P. Fish, docosahexaenoic acid and Alzheimer's disease. Prog Lipid Res. 2009;48(5):239-56. Epub 2009/04/14.

10. Salem N, Jr., Vandal M, Calon F. The benefit of docosahexaenoic acid for the adult brain in aging and dementia. Prostaglandins Leukot Essent Fatty Acids. 2015;92:15-22.

11. Barberger-Gateau P, Samieri C, Feart C, Plourde M. Dietary omega 3 polyunsaturated fatty acids and Alzheimer's disease: interaction with apolipoprotein E genotype. Curr Alzheimer Res. 2011;8(5):479-91.

12. Loef M, Walach H. The Omega-6/Omega-3 Ratio and Dementia or Cognitive Decline: A Systematic Review on Human Studies and Biological Evidence. Journal of Nutrition in Gerontology and Geriatrics. 2013;32(1):1-23. 
480

481

482

483

484

485

486

487

488

489

490

491

492

493

494

495

496

497

498

499

500

501

502

503

504

505

506

507

508

509

510

511

512

513

514

515

516

517

518

519

520

521

522

523

524

525

526

527

528

13. van der Lee SJ, Teunissen CE, Pool R, Shipley MJ, Teumer A, Chouraki V, et al. Circulating metabolites and general cognitive ability and dementia: Evidence from 11 cohort studies. Alzheimer's \& dementia : the journal of the Alzheimer's Association. 2018;14(6):707-22. Epub 2018/01/10.

14. Mc Auley MT, Mooney KM. Computationally Modeling Lipid Metabolism and Aging: A Mini-review. Computational and structural biotechnology journal. 2015;13:38-46. Epub 2015/03/10.

15. Schwenk RW, Holloway GP, Luiken JJ, Bonen A, Glatz JF. Fatty acid transport across the cell membrane: regulation by fatty acid transporters. Prostaglandins, leukotrienes, and essential fatty acids. 2010;82(4-6):149-54. Epub 2010/03/09.

16. Mu H, Hoy CE. The digestion of dietary triacylglycerols. Prog Lipid Res. 2004;43(2):105-33.

17. Mattson FH, Volpenhein RA. The Digestion and Absorption of Triglycerides. J Biol Chem. 1964;239:2772-7.

18. Kunisaki S, C. M. Ultrasound growth patterns of fetal lung malformations: Implications on prenatal care and postnatal outcome. Prenat Diagn. 2015;35(24):89-90.

19. D'Aquila T, Hung YH, Carreiro A, Buhman KK. Recent discoveries on absorption of dietary fat: Presence, synthesis, and metabolism of cytoplasmic lipid droplets within enterocytes. Biochimica et biophysica acta. 2016;1861(8 Pt A):730-47. Epub 2016/04/25.

20. Bisgaier CL, Glickman RM. Intestinal synthesis, secretion, and transport of lipoproteins. Annu Rev Physiol. 1983;45:625-36.

21. Mansbach CM, 2nd, Nevin P. Intracellular movement of triacylglycerols in the intestine. J Lipid Res. 1998;39(5):963-8.

22. Cooper AD. Hepatic uptake of chylomicron remnants. J Lipid Res. 1997;38(11):2173-92.

23. Redgrave TG, Small DM. Quantitation of the transfer of surface phospholipid of chylomicrons to the high density lipoprotein fraction during the catabolism of chylomicrons in the rat. J Clin Invest. 1979;64(1):162-71.

24. Gruffat D, Durand D, Graulet B, Bauchart D. Regulation of VLDL synthesis and secretion in the liver. Reprod Nutr Dev. 1996;36(4):375-89.

25. Havel RJ. The formation of LDL: mechanisms and regulation. J Lipid Res. 1984;25(13):1570-6.

26. Brown MS, Goldstein JL. A receptor-mediated pathway for cholesterol homeostasis. Science. 1986;232(4746):34-47.

27. Zhang Y, Ma KL, Ruan XZ, Liu BC. Dysregulation of the Low-Density Lipoprotein Receptor Pathway Is Involved in Lipid Disorder-Mediated Organ Injury. Int J Biol Sci. 2016;12(5):569-79.

28. B. B. Stress oxydant et pathologies cardiovasculaires. . Médecine Thérapeutique Cardiol. . 2006;2(1):43-52. 29. Fortier M, Tremblay-Mercier J, Plourde M, Chouinard-Watkins R, Vandal M, Pifferi F, et al. Higher plasma n-3 fatty acid status in the moderately healthy elderly in southern Quebec: higher fish intake or aging-related change in n-3 fatty acid metabolism? Prostaglandins, leukotrienes, and essential fatty acids. 2010;82(4-6):277-80. Epub 2010/03/09.

30. Einarsson K, Nilsell K, Leijd B, Angelin B. Influence of age on secretion of cholesterol and synthesis of bile acids by the liver. The New England journal of medicine. 1985;313(5):277-82. Epub 1985/08/01.

31. Verges B. Pathophysiology of diabetic dyslipidaemia: where are we? Diabetologia. 2015;58(5):886-99. 32. Austin MA, Hokanson JE, Edwards KL. Hypertriglyceridemia as a cardiovascular risk factor. Am J Cardiol. 1998;81(4A):7B-12B.

33. Ericsson S, Berglund L, Frostegard J, Einarsson K, Angelin B. The influence of age on low density lipoprotein metabolism: effects of cholestyramine treatment in young and old healthy male subjects. J Intern Med. 1997;242(4):329-37.

34. Russell DW, Setchell KD. Bile acid biosynthesis. Biochemistry. 1992;31(20):4737-49.

35. Grundy SM, Cleeman JI, Rifkind BM, Kuller LH. Cholesterol lowering in the elderly population. Coordinating Committee of the National Cholesterol Education Program. Arch Intern Med. 1999;159(15):1670-8.

36. Fernandez ML, West KL. Mechanisms by which dietary fatty acids modulate plasma lipids. J Nutr. 2005;135(9):2075-8.

37. Block RC, Harris WS, Pottala JV. Determinants of Blood Cell Omega-3 Fatty Acid Content. The open biomarkers journal. 2008;1:1-6. 
529 38. Gellert S, Schuchardt JP, Hahn A. Low long chain omega-3 fatty acid status in middle-aged women. 530 Prostaglandins Leukot Essent Fatty Acids. 2017;117:54-9.

531 39. Harris WS, Luo J, Pottala JV, Espeland MA, Margolis KL, Manson JE, et al. Red blood cell polyunsaturated 532 fatty acids and mortality in the Women's Health Initiative Memory Study. J Clin Lipidol. 2017;11(1):250-9 e5.

533 40. Harris WS, Pottala JV, Lacey SM, Vasan RS, Larson MG, Robins SJ. Clinical correlates and heritability of 534 erythrocyte eicosapentaenoic and docosahexaenoic acid content in the Framingham Heart Study. Atherosclerosis. 535 2012;225(2):425-31.

536 41. Harris WS, Pottala JV, Varvel SA, Borowski JJ, Ward JN, McConnell JP. Erythrocyte omega-3 fatty acids 537 increase and linoleic acid decreases with age: observations from 160,000 patients. Prostaglandins Leukot Essent 538 Fatty Acids. 2013;88(4):257-63.

539 42. Sands SA, Reid KJ, Windsor SL, Harris WS. The impact of age, body mass index, and fish intake on the EPA 540 and DHA content of human erythrocytes. Lipids. 2005;40(4):343-7.

541 43. Aarsetoey H, Ponitz V, Grundt H, Staines H, Harris WS, Nilsen DW. (n-3) Fatty acid content of red blood 542 cells does not predict risk of future cardiovascular events following an acute coronary syndrome. J Nutr. 543 2009;139(3):507-13.

544 44. Block RC, Harris WS, Reid KJ, Sands SA, Spertus JA. EPA and DHA in blood cell membranes from acute 545 coronary syndrome patients and controls. Atherosclerosis. 2008;197(2):821-8.

546 45. Caprari P, Scuteri A, Salvati AM, Bauco C, Cantafora A, Masella R, et al. Aging and red blood cell 547 membrane: a study of centenarians. Exp Gerontol. 1999;34(1):47-57.

548 46. Carver JD, Benford VJ, Han B, Cantor AB. The relationship between age and the fatty acid composition of 549 cerebral cortex and erythrocytes in human subjects. Brain Res Bull. 2001;56(2):79-85.

550 47. Farzaneh-Far R, Harris WS, Garg S, Na B, Whooley MA. Inverse association of erythrocyte n-3 fatty acid 551 levels with inflammatory biomarkers in patients with stable coronary artery disease: The Heart and Soul Study. 552 Atherosclerosis. 2009;205(2):538-43.

553 48. Itomura M, Fujioka S, Hamazaki K, Kobayashi K, Nagasawa T, Sawazaki S, et al. Factors influencing 554 EPA+DHA levels in red blood cells in Japan. In vivo. 2008;22(1):131-5.

555 49. Thorlaksdottir AY, Skuladottir GV, Petursdottir AL, Tryggvadottir L, Ogmundsdottir HM, Eyfjord JE, et al. 556 Positive association between plasma antioxidant capacity and n-3 PUFA in red blood cells from women. Lipids. 557 558 559 560 561 562 563 564 565 566 567 568 569 570 571 572 573 574 575 576 577 2006;41(2):119-25.

50. Yanagisawa N, Shimada K, Miyazaki T, Kume A, Kitamura Y, Ichikawa R, et al. Polyunsaturated fatty acid levels of serum and red blood cells in apparently healthy Japanese subjects living in an urban area. Journal of atherosclerosis and thrombosis. 2010;17(3):285-94.

51. Brenna JT, Plourde M, Stark KD, Jones PJ, Lin YH. Best practices for the design, laboratory analysis, and reporting of trials involving fatty acids. Am J Clin Nutr. 2018;108(2):211-27.

52. Asciutti-Moura LS, Guilland JC, Fuchs F, Richard D, Klepping J. Fatty acid composition of serum lipids and its relation to diet in an elderly institutionalized population. Am J Clin Nutr. 1988;48(4):980-7.

53. Crowe FL, Skeaff CM, Green TJ, Gray AR. Serum n-3 long-chain PUFA differ by sex and age in a populationbased survey of New Zealand adolescents and adults. Br J Nutr. 2008;99(1):168-74.

54. de Groot RH, van Boxtel MP, Schiepers OJ, Hornstra G, Jolles J. Age dependence of plasma phospholipid fatty acid levels: potential role of linoleic acid in the age-associated increase in docosahexaenoic acid and eicosapentaenoic acid concentrations. Br J Nutr. 2009;102(7):1058-64.

55. Dewailly E, Blanchet C, Gingras S, Lemieux S, Holub BJ. Cardiovascular disease risk factors and n-3 fatty acid status in the adult population of James Bay Cree. Am J Clin Nutr. 2002;76(1):85-92.

56. Dewailly E, Blanchet $C$, Lemieux S, Sauve L, Gingras S, Ayotte $P$, et al. n-3 Fatty acids and cardiovascular disease risk factors among the Inuit of Nunavik. Am J Clin Nutr. 2001;74(4):464-73.

57. Dewailly EE, Blanchet C, Gingras S, Lemieux S, Sauve L, Bergeron J, et al. Relations between n-3 fatty acid status and cardiovascular disease risk factors among Quebecers. Am J Clin Nutr. 2001;74(5):603-11.

58. Ogura T, Takada H, Okuno M, Kitade H, Matsuura T, Kwon M, et al. Fatty acid composition of plasma, erythrocytes and adipose: their correlations and effects of age and sex. Lipids. 2010;45(2):137-44. 
578 59. Flock MR, Skulas-Ray AC, Harris WS, Etherton TD, Fleming JA, Kris-Etherton PM. Determinants of 579 erythrocyte omega-3 fatty acid content in response to fish oil supplementation: a dose-response randomized

580 581 582 583 584 585 586 587 588 589 590 591 592 593 594 595 596 597 598 599 600 601 602 603 604 605 606 607 608 609 610 611 612 613 614 615 616 617 618 619 620 621 622 623 624 625 controlled trial. Journal of the American Heart Association. 2013;2(6):e000513.

60. Witt PM, Christensen JH, Ewertz M, Aardestrup IV, Schmidt EB. The incorporation of marine n-3 PUFA into platelets and adipose tissue in pre- and postmenopausal women: a randomised, double-blind, placebo-controlled trial. Br J Nutr. 2010;104(3):318-25.

61. Vandal M, Freemantle E, Tremblay-Mercier J, Plourde M, Fortier M, Bruneau J, et al. Plasma omega-3 fatty acid response to a fish oil supplement in the healthy elderly. Lipids. 2008;43(11):1085-9.

62. Fortier $M$, Tremblay-Mercier J, Plourde $M$, Chouinard-Watkins $R$, Vandal M, Pifferi $F$, et al. Higher plasma n-3 fatty acid status in the moderately healthy elderly in southern Quebec: higher fish intake or aging-related change in n-3 fatty acid metabolism? Prostaglandins Leukot Essent Fatty Acids. 2010;82(4-6):277-80.

63. Meydani M, Natiello F, Goldin B, Free N, Woods M, Schaefer E, et al. Effect of long-term fish oil supplementation on vitamin $E$ status and lipid peroxidation in women. J Nutr. 1991;121(4):484-91.

64. Meydani SN, Endres S, Woods MM, Goldin BR, Soo C, Morrill-Labrode A, et al. Oral (n-3) fatty acid supplementation suppresses cytokine production and lymphocyte proliferation: comparison between young and older women. J Nutr. 1991;121(4):547-55.

65. Plourde M, Tremblay-Mercier J, Fortier M, Pifferi F, Cunnane SC. Eicosapentaenoic acid decreases postprandial beta-hydroxybutyrate and free fatty acid responses in healthy young and elderly. Nutrition. 2009;25(3):289-94.

66. Rees D, Miles EA, Banerjee T, Wells SJ, Roynette CE, Wahle KW, et al. Dose-related effects of eicosapentaenoic acid on innate immune function in healthy humans: a comparison of young and older men. Am J Clin Nutr. 2006;83(2):331-42.

67. Walker CG, Browning LM, Mander AP, Madden J, West AL, Calder PC, et al. Age and sex differences in the incorporation of EPA and DHA into plasma fractions, cells and adipose tissue in humans. Br J Nutr. 2014;111(4):679-89.

68. Vandal M, Freemantle E, Tremblay-Mercier J, Plourde M, Fortier M, Bruneau J, et al. Plasma omega-3 fatty acid response to a fish oil supplement in the healthy elderly. Lipids. 2008;43(11):1085-9.

69. Brossard N, Croset M, Normand S, Pousin J, Lecerf J, Laville M, et al. Human plasma albumin transports [13C]docosahexaenoic acid in two lipid forms to blood cells. J Lipid Res. 1997;38(8):1571-82.

70. Brossard N, Croset M, Pachiaudi C, Riou JP, Tayot JL, Lagarde M. Retroconversion and metabolism of [13C]22:6n-3 in humans and rats after intake of a single dose of [13C]22:6n-3-triacylglycerols. Am J Clin Nutr. 1996;64(4):577-86.

71. Lemaitre-Delaunay D, Pachiaudi C, Laville M, Pousin J, Armstrong M, Lagarde M. Blood compartmental metabolism of docosahexaenoic acid (DHA) in humans after ingestion of a single dose of $\left[\left({ }^{13}\right) \mathrm{C}\right] \mathrm{DHA}$ in phosphatidylcholine. J Lipid Res. 1999;40(10):1867-74.

72. Fortier M, Tremblay-Mercier J, Plourde M, Chouinard-Watkins R, Vandal M, Pifferi F, et al. Higher plasma n-3 fatty acid status in the moderately healthy elderly in southern Quebec: higher fish intake or aging-related change in n-3 fatty acid metabolism? Prostaglandins Leukot Essent Fatty Acids. ;82(4-6):277-80. Epub 2010/03/09. 73. Plourde $\mathrm{M}$, Chouinard-Watkins $\mathrm{R}$, Vandal $\mathrm{M}$, Zhang $\mathrm{Y}$, Lawrence $\mathrm{P}$, Brenna JT, et al. Plasma incorporation, apparent retroconversion and beta-oxidation of 13C-docosahexaenoic acid in the elderly. Nutrition \& metabolism. 2011;8:5. Epub 2011/01/29.

74. Leveille P, Chouinard-Watkins R, Windust A, Lawrence P, Cunnane SC, Brenna JT, et al. Metabolism of uniformly labeled 13C-eicosapentaenoic acid and 13C-arachidonic acid in young and old men. Am J Clin Nutr. 2017.

75. Hedman AM, van Haren NE, Schnack HG, Kahn RS, Hulshoff Pol HE. Human brain changes across the life span: a review of 56 longitudinal magnetic resonance imaging studies. Hum Brain Mapp. 2012;33(8):1987-2002. 76. Coffey CE, Lucke JF, Saxton JA, Ratcliff G, Unitas L, Billig B, et al. Sex differences in brain aging: a quantitative magnetic resonance imaging study. Arch Neurol. 1998;55(2):169-79. 
626

627

628

629

630

631

632

633

634

635

636

637

638

639

640

641

642

643

644

645

646

647

648

649

650

651

652

653

654

655

656

657

658

659

660

661

662

663

664

665

666

667

668

669

670

671

672

673

674

77. Murphy DG, DeCarli C, McIntosh AR, Daly E, Mentis MJ, Pietrini P, et al. Sex differences in human brain morphometry and metabolism: an in vivo quantitative magnetic resonance imaging and positron emission tomography study on the effect of aging. Arch Gen Psychiatry. 1996;53(7):585-94.

78. Bourisly AK, El-Beltagi A, Cherian J, Gejo G, Al-Jazzaf A, Ismail M. A voxel-based morphometric magnetic resonance imaging study of the brain detects age-related gray matter volume changes in healthy subjects of 21-45 years old. The neuroradiology journal. 2015;28(5):450-9.

79. Draganski B, Ashburner J, Hutton C, Kherif F, Frackowiak RS, Helms G, et al. Regional specificity of MRI contrast parameter changes in normal ageing revealed by voxel-based quantification (VBQ). Neuroimage. 2011;55(4):1423-34.

80. Hafkemeijer A, Altmann-Schneider I, de Craen AJ, Slagboom PE, van der Grond J, Rombouts SA. Associations between age and gray matter volume in anatomical brain networks in middle-aged to older adults. Aging Cell. 2014;13(6):1068-74.

81. Jancke L, Merillat S, Liem F, Hanggi J. Brain size, sex, and the aging brain. Hum Brain Mapp. 2015;36(1):150-69.

82. Minkova L, Habich A, Peter J, Kaller CP, Eickhoff SB, Kloppel S. Gray matter asymmetries in aging and neurodegeneration: A review and meta-analysis. Hum Brain Mapp. 2017;38(12):5890-904.

83. Peng F, Wang L, Geng Z, Zhu Q, Song Z. A Cross-Sectional Voxel-Based Morphometric Study of Age- and Sex-Related Changes in Gray Matter Volume in the Normal Aging Brain. Journal of computer assisted tomography. 2016;40(2):307-15.

84. Tremblay P, Dick AS, Small SL. Functional and structural aging of the speech sensorimotor neural system: functional magnetic resonance imaging evidence. Neurobiol Aging. 2013;34(8):1935-51.

85. Callaghan MF, Freund P, Draganski B, Anderson E, Cappelletti M, Chowdhury R, et al. Widespread agerelated differences in the human brain microstructure revealed by quantitative magnetic resonance imaging. Neurobiol Aging. 2014;35(8):1862-72.

86. Honda Y, Noguchi A, Maruyama K, Tamura A, Saito I, Sei K, et al. Volumetric analyses of cerebral white matter hyperintensity lesions on magnetic resonance imaging in a Japanese population undergoing medical checkup. Geriatrics \& gerontology international. 2015;15 Suppl 1:43-7.

87. Liu H, Wang L, Geng Z, Zhu Q, Song Z, Chang R, et al. A voxel-based morphometric study of age- and sexrelated changes in white matter volume in the normal aging brain. Neuropsychiatric disease and treatment. 2016;12:453-65.

88. Coffler MS, Patel K, Dahan MH, Yoo RY, Malcom PJ, Chang RJ. Enhanced granulosa cell responsiveness to follicle-stimulating hormone during insulin infusion in women with polycystic ovary syndrome treated with pioglitazone. J Clin Endocrinol Metab. 2003;88(12):5624-31. Epub 2003/12/13.

89. Xu J, Kobayashi S, Yamaguchi S, lijima K, Okada K, Yamashita K. Gender effects on age-related changes in brain structure. AJNR Am J Neuroradiol. 2000;21(1):112-8.

90. Van Der Werf YD, Tisserand DJ, Visser PJ, Hofman PA, Vuurman E, Uylings HB, et al. Thalamic volume predicts performance on tests of cognitive speed and decreases in healthy aging. A magnetic resonance imagingbased volumetric analysis. Brain research. Cognitive brain research. 2001;11(3):377-85.

91. Erten-Lyons D, Dodge HH, Woltjer R, Silbert LC, Howieson DB, Kramer P, et al. Neuropathologic basis of age-associated brain atrophy. JAMA Neurol. 2013;70(5):616-22.

92. Fjell AM, Westlye LT, Grydeland H, Amlien I, Espeseth T, Reinvang I, et al. Critical ages in the life course of the adult brain: nonlinear subcortical aging. Neurobiol Aging. 2013;34(10):2239-47.

93. Fraser MA, Shaw ME, Cherbuin N. A systematic review and meta-analysis of longitudinal hippocampal atrophy in healthy human ageing. Neuroimage. 2015;112:364-74.

94. Onozuka M, Fujita M, Watanabe K, Hirano Y, Niwa M, Nishiyama K, et al. Age-related changes in brain regional activity during chewing: a functional magnetic resonance imaging study. Journal of dental research. 2003;82(8):657-60.

95. Heuninckx S, Wenderoth N, Swinnen SP. Systems neuroplasticity in the aging brain: recruiting additional neural resources for successful motor performance in elderly persons. J Neurosci. 2008;28(1):91-9. 
675

676

677

678

679

680

681

682

683

684

685

686

687

688

689

690

691

692

693

694

695

696

697

698

699

700

701

702

703

704

705

706

707

708

709

710

711

712

713

714

715

716

717

718

719

720

721

722

723

96. Holtzer R, Epstein N, Mahoney JR, Izzetoglu M, Blumen HM. Neuroimaging of mobility in aging: a targeted review. The journals of gerontology. Series A, Biological sciences and medical sciences. 2014;69(11):1375-88. 97. Kim JH, Lee YS, Lee JJ, Song HJ, Yoo DS, Lee HJ, et al. Functional magnetic resonance imaging reveals agerelated alterations to motor networks in weighted elbow flexion-extension movement. Neurological research. 2010;32(9):995-1001.

98. Linortner $\mathrm{P}$, Jehna $\mathrm{M}$, Johansen-Berg $\mathrm{H}$, Matthews $\mathrm{P}$, Schmidt R, Fazekas $\mathrm{F}$, et al. Aging associated changes in the motor control of ankle movements in the brain. Neurobiol Aging. 2014;35(10):2222-9.

99. Gunning-Dixon FM, Raz N. The cognitive correlates of white matter abnormalities in normal aging: a quantitative review. Neuropsychology. 2000;14(2):224-32.

100. Yuan P, Raz N. Prefrontal cortex and executive functions in healthy adults: a meta-analysis of structural neuroimaging studies. Neurosci Biobehav Rev. 2014;42:180-92.

101. Van Petten C. Relationship between hippocampal volume and memory ability in healthy individuals across the lifespan: review and meta-analysis. Neuropsychologia. 2004;42(10):1394-413.

102. O'Shea A, Cohen RA, Porges EC, Nissim NR, Woods AJ. Cognitive Aging and the Hippocampus in Older Adults. Front Aging Neurosci. 2016;8:298.

103. Gonneaud J, Lecouvey G, Groussard M, Gaubert M, Landeau B, Mezenge F, et al. Functional dedifferentiation and reduced task-related deactivations underlie the age-related decline of prospective memory. Brain imaging and behavior. 2017;11(6):1873-84.

104. Meusel LA, Grady CL, Ebert PE, Anderson ND. Brain-behavior relationships in source memory: Effects of age and memory ability. Cortex. 2017;91:221-33.

105. Rieckmann A, Pudas S, Nyberg L. Longitudinal Changes in Component Processes of Working Memory. eNeuro. 2017;4(2).

106. Suzuki Y, Critchley HD, Suckling J, Fukuda R, Williams SC, Andrew C, et al. Functional magnetic resonance imaging of odor identification: the effect of aging. The journals of gerontology. Series A, Biological sciences and medical sciences. 2001;56(12):M756-60.

107. Fusar-Poli P, Placentino A, Carletti F, Landi P, Allen P, Surguladze S, et al. Functional atlas of emotional faces processing: a voxel-based meta-analysis of 105 functional magnetic resonance imaging studies. Journal of psychiatry \& neuroscience : JPN. 2009;34(6):418-32.

108. Grady CL. Age-related differences in face processing: a meta-analysis of three functional neuroimaging experiments. Canadian journal of experimental psychology = Revue canadienne de psychologie experimentale. 2002;56(3):208-20.

109. Daneault V, Hebert M, Albouy G, Doyon J, Dumont M, Carrier J, et al. Aging reduces the stimulating effect of blue light on cognitive brain functions. Sleep. 2014;37(1):85-96.

110. Sala-Llonch R, Junque C, Arenaza-Urquijo EM, Vidal-Pineiro D, Valls-Pedret C, Palacios EM, et al. Changes in whole-brain functional networks and memory performance in aging. Neurobiol Aging. 2014;35(10):2193-202.

111. Tomasi D, Volkow ND. Aging and functional brain networks. Molecular psychiatry. 2012;17(5):471, 549-58. 112. Archer JA, Lee A, Qiu A, Chen SH. A Comprehensive Analysis of Connectivity and Aging Over the Adult Life Span. Brain connectivity. 2016;6(2):169-85.

113. Geerligs L, Maurits NM, Renken RJ, Lorist MM. Reduced specificity of functional connectivity in the aging brain during task performance. Hum Brain Mapp. 2014;35(1):319-30.

114. Zhang $\mathrm{H}$, Lee A, Qiu A. A posterior-to-anterior shift of brain functional dynamics in aging. Brain structure \& function. 2017;222(8):3665-76.

115. Naber D, Dahnke HG. Protein and nucleic acid content in the aging human brain. Neuropathology and applied neurobiology. 1979;5(1):17-24.

116. Soderberg M, Edlund C, Kristensson K, Dallner G. Lipid compositions of different regions of the human brain during aging. J Neurochem. 1990;54(2):415-23. Epub 1990/02/01.

117. Surowka AD, Adamek D, Radwanska E, Szczerbowska-Boruchowska M. Variability of protein and lipid composition of human subtantia nigra in aging: Fourier transform infrared microspectroscopy study. Neurochem Int. 2014;76:12-22. 
724

725

726

727

728

729

730

731

732

733

734

735

736

737

738

739

740

741

742

743

744

745

746

747

748

749

750

751

752

753

754

755

756

757

758

759

760

761

762

763

764

765

766

767

768

769

770

771
118. Svennerholm L, Bostrom K, Jungbjer B, Olsson L. Membrane lipids of adult human brain: lipid composition of frontal and temporal lobe in subjects of age 20 to 100 years. J Neurochem. 1994;63(5):1802-11. Epub 1994/11/01.

119. Hancock SE, Friedrich MG, Mitchell TW, Truscott RJ, Else PL. The phospholipid composition of the human entorhinal cortex remains relatively stable over 80 years of adult aging. GeroScience. 2017;39(1):73-82.

120. Norris SE, Friedrich MG, Mitchell TW, Truscott RJW, Else PL. Human prefrontal cortex phospholipids containing docosahexaenoic acid increase during normal adult aging, whereas those containing arachidonic acid decrease. Neurobiol Aging. 2015;36(4):1659-69.

121. Yassine HN, Croteau E, Rawat V, Hibbeln JR, Rapoport SI, Cunnane SC, et al. DHA brain uptake and APOE4 status: a PET study with [1-(11)C]-DHA. Alzheimers Res Ther. 2017;9(1):23.

122. Coon KD, Myers AJ, Craig DW, Webster JA, Pearson JV, Lince DH, et al. A high-density whole-genome association study reveals that APOE is the major susceptibility gene for sporadic late-onset Alzheimer's disease. J Clin Psychiatry. 2007;68(4):613-8.

123. Chouinard-Watkins R, Conway V, Minihane AM, Jackson KG, Lovegrove JA, Plourde M. Interactive impact of $\mathrm{BMI}$ and $\mathrm{APOE}$ genotype on the plasma long chain polyunsaturated fatty acid response to a fish oil supplement in healthy participants Am J Clin Nutr. 2015;102:505-13.

124. Chouinard-Watkins R, Rioux-Perreault C, Fortier M, Tremblay-Mercier J, Zhang Y, Lawrence P, et al. Disturbance in uniformly 13C-labelled DHA metabolism in elderly human subjects carrying the apoE epsilon4 allele. Br J Nutr. 2013;110(10):1751-9. Epub 2013/05/02.

125. Conway V, Allard MJ, Minihane AM, Jackson KG, Lovegrove JA, Plourde M. Postprandial enrichment of triacylglycerol-rich lipoproteins with omega-3 fatty acids: lack of an interaction with apolipoprotein E genotype? Lipids Health Dis. 2014;13(1):148. Epub 2014/09/18.

126. Plourde $M$, Vohl MC, Vandal $M$, Couture $P$, Lemieux $S$, Cunnane SC. Plasma $n-3$ fatty acid response to an $n-$ 3 fatty acid supplement is modulated by apoE epsilon4 but not by the common PPAR-alpha L162V polymorphism in men. Br J Nutr. 2009;102(8):1121-4. Epub 2009/10/16.

127. Nock TG, Chouinard-Watkins R, Plourde M. Carriers of an apolipoprotein E epsilon 4 allele are more vulnerable to a dietary deficiency in omega-3 fatty acids and cognitive decline. Biochim Biophys Acta.

2017;1862(10 Pt A):1068-78.

128. Gu Y, Vorburger RS, Gazes Y, Habeck CG, Stern Y, Luchsinger JA, et al. White matter integrity as a mediator in the relationship between dietary nutrients and cognition in the elderly. Ann Neurol. 2016;79(6):1014-25.

129. Raji CA, Erickson KI, Lopez OL, Kuller LH, Gach HM, Thompson PM, et al. Regular fish consumption and agerelated brain gray matter loss. American journal of preventive medicine. 2014;47(4):444-51.

130. Samieri C, Maillard P, Crivello F, Proust-Lima C, Peuchant E, Helmer C, et al. Plasma long-chain omega-3 fatty acids and atrophy of the medial temporal lobe. Neurology. 2012;79(7):642-50.

131. Witte AV, Kerti L, Hermannstadter HM, Fiebach JB, Schreiber SJ, Schuchardt JP, et al. Long-chain omega-3 fatty acids improve brain function and structure in older adults. Cereb Cortex. 2014;24(11):3059-68.

132. Salthouse TA, Mitchell DR, Palmon R. Memory and age differences in spatial manipulation ability. Psychol Aging. 1989;4(4):480-6. Epub 1989/12/01.

133. Salthouse TA, Mitchell DR, Skovronek E, Babcock RL. Effects of adult age and working memory on reasoning and spatial abilities. J Exp Psychol Learn Mem Cogn. 1989;15(3):507-16. Epub 1989/05/01.

134. Blennow K, de Leon MJ, Zetterberg H. Alzheimer's disease. Lancet. 2006;368(9533):387-403.

135. Deary IJ, Whiteman MC, Pattie A, Starr JM, Hayward C, Wright AF, et al. Cognitive change and the APOE epsilon 4 allele. Nature. 2002;418(6901):932.

136. Hoyer $\mathrm{S}$. The aging brain. Changes in the neuronal insulin/insulin receptor signal transduction cascade trigger late-onset sporadic Alzheimer disease (SAD). A mini-review. J Neural Transm. 2002;109(7-8):991-1002. 137. Rosenberg A, Ngandu T, Rusanen M, Antikainen R, Backman L, Havulinna S, et al. Multidomain lifestyle intervention benefits a large elderly population at risk for cognitive decline and dementia regardless of baseline characteristics: The FINGER trial. Alzheimers Dement. 2018;14(3):263-70. 
772 138. Lehtisalo J, Levalahti E, Lindstrom J, Hanninen T, Paajanen T, Peltonen M, et al. Dietary changes and 773 cognition over 2 years within a multidomain intervention trial-The Finnish Geriatric Intervention Study to Prevent 774 Cognitive Impairment and Disability (FINGER). Alzheimers Dement. 2018.

775 139. Croteau E, Castellano CA, Fortier M, Bocti C, Fulop T, Paquet N, et al. A cross-sectional comparison of brain 776 glucose and ketone metabolism in cognitively healthy older adults, mild cognitive impairment and early 777 Alzheimer's disease. Exp Gerontol. 2018;107:18-26.

778 140. Croteau E, Castellano CA, Richard MA, Fortier M, Nugent S, Lepage M, et al. Ketogenic Medium Chain 779 Triglycerides Increase Brain Energy Metabolism in Alzheimer's Disease. J Alzheimers Dis. 2018;64(2):551-61. 780 141. Nogi A, Yang J, Li L, Yamasaki M, Watanabe M, Hashimoto M, et al. Plasma n-3 polyunsaturated fatty acid 781 and cardiovascular disease risk factors in Japanese, Korean and Mongolian workers. Journal of occupational 782 health. 2007;49(3):205-16.

783 142. Skuladottir GV, Gudmundsdottir S, Olafsson GB, Sigurdsson SB, Sigfusson N, Axelsson J. Plasma fatty acids 784 785 786 787 788 789 790 791 792 793 and lipids in two separate, but genetically comparable, Icelandic populations. Lipids. 1995;30(7):649-55. 143. Stark KD, Park EJ, Holub BJ. Fatty acid composition of serum phospholipid of premenopausal women and postmenopausal women receiving and not receiving hormone replacement therapy. Menopause. 2003;10(5):44855.

144. Stark KD, Beblo S, Murthy M, Whitty JE, Buda-Abela M, Janisse J, et al. Alcohol consumption in pregnant, black women is associated with decreased plasma and erythrocyte docosahexaenoic acid. Alcoholism, clinical and experimental research. 2005;29(1):130-40.

145. Yesilyurt B, Whittingstall K, Ugurbil K, Logothetis NK, Uludag K. Relationship of the BOLD signal with VEP for ultrashort duration visual stimuli (0.1 to $5 \mathrm{~ms}$ ) in humans. J Cereb Blood Flow Metab. 2010;30(2):449-58. Epub 2009/10/22. 


\begin{tabular}{|c|c|c|c|c|c|c|}
\hline \multirow[b]{2}{*}{ Reference } & \multirow[b]{2}{*}{$n$, sex and age } & \multirow[b]{2}{*}{ Blood pool } & \multirow[b]{2}{*}{ Age-increasing effects } & \multicolumn{3}{|c|}{ Age-increasing effects at baseline in blood pool } \\
\hline & & & & Omega-3 index & EPA & DHA \\
\hline 43 & $\begin{array}{l}\mathrm{n}=460,299 \text { men and } 161 \\
\text { women, } 29-97 \mathrm{y}(\sim 72 \mathrm{y})\end{array}$ & RBC & $\begin{array}{l}9.8 \text { y older in Higher Omega-3 } \\
\text { Index Quartile compared to } \\
\text { Lower Quartile }\end{array}$ & $\begin{array}{l}\text { Higher Omega- } \\
3 \text { Index quartile } \\
\text { were } 9.8 \text { y } \\
\text { older vs lower } \\
\text { quartile }\end{array}$ & & \\
\hline 52 & $\begin{array}{l}53 \quad \text { institutionalized } \\
\text { elderly subjects ( } 24 \text { men } \\
\text { and } 29 \text { women), } \geq 60 \text { y ( } \\
79 \text { y); } 24 \text { young healthy } \\
\text { adults, } 20-42 \text { y }(\sim 29 \text { y) }\end{array}$ & $\begin{array}{l}\text { Plasma NEFA, TG, CE } \\
\text { and PL }\end{array}$ & $\begin{array}{l}\text { In plasma PL: EPA higher in } \\
\text { elderly; DHA and DPA: appear } \\
\text { lower in the elderly but non- } \\
\text { significantly different }\end{array}$ & & $\begin{array}{l}\text { PL: } 2.1 \text { fold } \\
\text { higher }\end{array}$ & \\
\hline 44 & $\begin{array}{l}768 \text { acute coronary } \\
\text { syndrome patients and } \\
768 \text { matched controls ( } 66 \\
\% \text { male, } \sim 61 \mathrm{y} \text { ) }\end{array}$ & RBC membranes & $\begin{array}{l}\text { Positive relation between age } \\
\text { and EPA and DHA levels: } 8 \text { years } \\
\text { older in those with higher EPA + } \\
\text { DHA levels vs those with lower } \\
\text { group }\end{array}$ & & $\begin{array}{l}\text { Higher RBC EPA } \\
+ \text { DHA group: } 8 \\
\text { y older } \\
\text { compared to } \\
\text { Lower group }\end{array}$ & $\begin{array}{l}\text { Higher RBC EPA } \\
+ \text { DHA group: } 8 \\
\text { y older } \\
\text { compared to } \\
\text { Lower group }\end{array}$ \\
\hline 37 & $\begin{array}{l}704 \text { outpatients }(67 \% \\
\text { male), } 62 \mathrm{y}\end{array}$ & RBC & $\begin{array}{l}\text { RBC Omega-3 Index increases } \\
\text { with age }\end{array}$ & $\begin{array}{l}5.3 \% \text { increase } \\
\text { by } 10 \text { years } \\
\text { increase }\end{array}$ & & \\
\hline 45 & $\begin{array}{l}15 \text { centenarians (12 } \\
\text { females and } 3 \text { males), } \\
103 \text { y (101-107 y), living } \\
\text { in a family unit, self- } \\
\text { sufficient and without } \\
\text { major illnesses and } 13 \\
\text { normal subjects ( } 6 \text { males } \\
\text { and } 7 \text { females), } 65 \text { y (6.0 } \\
\text { - } 69 \text { y) }\end{array}$ & RBC-PL & $\begin{array}{l}\text { Increased DHA in RBC-PC and in } \\
\text { RBC-PE, and increased DPA in } \\
\text { RBC-PS and RBC-PE; }\end{array}$ & & & $\begin{array}{l}\text { PC: } 2.2 \text { fold } \\
\text { higher } \quad \text { PE: } \\
\text { 1.6 fold higher }\end{array}$ \\
\hline 53 & $\begin{array}{l}2793 \text { New Zealanders } \geq 15 \\
\text { y (men and women) }\end{array}$ & Serum PL, CE and TG & $\begin{array}{l}\text { Serum PL: EPA and DHA } \\
\text { increase with age in both sexes } \\
\text { while DPA increases with age } \\
\text { only in women aged between of } \\
20 \text { and } 73 y\end{array}$ & & $\begin{array}{l}\text { PL: in both } \\
\text { sexes, } \\
\text { increased by } \\
0.3 \quad \text { mol\% } \\
\text { between } 20 \\
\text { and } 73 \text { y }\end{array}$ & $\begin{array}{l}\mathrm{PL}: \text { in both } \\
\text { sexes, increased } \\
\text { by } 0.3 \text { mol\% } \\
\text { between } 20 \text { and } \\
73 \mathrm{y}\end{array}$ \\
\hline
\end{tabular}




\begin{tabular}{|c|c|c|c|c|c|c|}
\hline 54 & $\begin{array}{l}234 \text { men and women } \\
\text { (Dutch: low fish } \\
\text { consumption), } 36 \text { to } 88 \\
\text { years }(\sim 60 \mathrm{y})\end{array}$ & Plasma PL & $\begin{array}{l}\text { Significant positive relationship } \\
\text { between age and plasma PL } \\
\text { concentrations of DHA and EPA. }\end{array}$ & & $\begin{array}{l}\text { PL: } 1.5 \text { fold } \\
\text { increased } \\
\text { between } 36 \text { to } \\
88 \mathrm{y}\end{array}$ & $\begin{array}{l}\text { PL: } 1.3 \text { fold } \\
\text { increased } \\
\text { between } 36 \text { to } \\
88 \mathrm{y}\end{array}$ \\
\hline 56 & $\begin{array}{l}426 \text { Inuits, } 18 \text { to } 74 \text { years: } \\
179 \text { men }(\sim 38.7 \text { y) and } \\
247 \text { women }(\sim 37.8 \text { y), } \\
n=254 \text { in } 18-39 \text { y and } \\
n=172 \text { in } \geq 40 y\end{array}$ & Plasma PL & $\begin{array}{l}\text { Concentrations of EPA, DHA } \\
\text { and EPA + DHA increased } \\
\text { significantly with age }\end{array}$ & & $\begin{array}{l}2.4 \text { fold higher } \\
\text { in } \geq 40 \text { y group } \\
\text { compared to } \\
18-39 \text { y group }\end{array}$ & $\begin{array}{l}1.4 \text { fold higher in } \\
\geq 40 \text { y group } \\
\text { compared to } 18- \\
39 \text { y group }\end{array}$ \\
\hline 57 & $\begin{array}{l}1460 \text { subjects, } 18-74 \\
\text { years: } 722 \text { men }(\sim 40.6 \text { y) } \\
\text { and } 738 \text { women }(\sim 39.6 y) \text {, } \\
n=784 \text { in } 18-34 y, n=432 \text { in } \\
35-49 \text { y and } n=244 \text { in } 50- \\
74 \text { y }\end{array}$ & Plasma PL & $\begin{array}{l}\text { Older persons had higher EPA, } \\
\text { DHA, EPA+DHA, EPA: AA and n- } \\
3: n-6 \text { ratio in older vs younger } \\
\text { individuals }\end{array}$ & & $\begin{array}{l}1.1 \text { fold higher } \\
\text { in } 50-74 \text { y } \\
\text { compared to } \\
18-34 \text { y }\end{array}$ & $\begin{array}{l}1.2 \text { fold higher in } \\
50-74 \\
\text { compared to } 18- \\
34 \text { y }\end{array}$ \\
\hline 55 & $\begin{array}{l}917 \text { subjects, } 18-74 \text { y: } 422 \\
\text { men }(\sim 36.0 y) \text { and } 495 \\
\text { women }(\sim 35.6 \text { y), } n=536 \\
\text { in } 18-34 y, n=220 \text { in } 35-49 \\
y \text { and } n=161 \text { in } 50-74 y\end{array}$ & Plasma PL & $\begin{array}{l}\text { EPA: AA, n- } 3 \text { : } n-6 \text { FA, and } \\
\text { concentrations of EPA, DHA, } \\
\text { and EPA+DHA did not vary } \\
\text { according to sex, but there was } \\
\text { a significant increase in the } \\
\text { concentrations with age }\end{array}$ & & $\begin{array}{l}2.5 \text { fold higher } \\
\text { in } 50-74 \text { y } \\
\text { compared to } \\
18-34 \text { y }\end{array}$ & $\begin{array}{l}1.7 \text { fold higher in } \\
50-74 \quad y \\
\text { compared to } 18- \\
34 \text { y }\end{array}$ \\
\hline 47 & $\begin{array}{l}992 \text { participants (mainly } \\
\text { men: }>80 \% \text { ), age: early } \\
50 \text { s to late } 70 \text { s }\end{array}$ & RBC membranes & $\begin{array}{l}\text { Lower levels EPA + DHA were } \\
\text { significantly associated with } \\
\text { younger age }\end{array}$ & & & \\
\hline 38 & $\begin{array}{l}446 \text { women, } \sim 48,5 \quad y \\
(40-60 \mathrm{y})\end{array}$ & RBC membrane & $\begin{array}{l}\text { In women aged } \geq 50 \text { years, EPA } \\
\text { and DPA levels and omega- } 3 \\
\text { index were significantly higher } \\
\text { compared to women under the } \\
\text { age of } 50 \text { years. }\end{array}$ & $\begin{array}{l}4 \% \text { higher in } \\
\geq 50 \quad y \\
\text { compared } \text { to } \\
<50 y\end{array}$ & $\begin{array}{l}13 \% \text { higher in } \\
\geq 50 \text { y } \\
\text { compared to } \\
<50 y\end{array}$ & \\
\hline 40 & $\begin{array}{l}\mathrm{n}=3196,55 \% \text { women, } \\
\sim 66 \mathrm{y}(40-74 \mathrm{y})\end{array}$ & RBC & $\begin{array}{l}\text { RBC Omega-3 Index increases } \\
\text { with age }\end{array}$ & $\begin{array}{l}5 \% \text { increase } \\
\text { every decade }\end{array}$ & & \\
\hline
\end{tabular}




\begin{tabular}{|c|c|c|c|c|c|c|}
\hline 41 & $\begin{array}{l}159771 \text { patients (48\% } \\
\text { males, } 52 \% \text { females) } \\
\text { being evaluated by their } \\
\text { physicians for CVD risk }\end{array}$ & RBC & $\begin{array}{l}\text { Increases in EPA and DHA each } \\
\text { decade. After age 70, significant } \\
\text { decrease in EPA while DHA } \\
\text { remain high }\end{array}$ & $\begin{array}{l}7 \% \text { increase by } \\
\text { decade until } 70 \\
y, \quad \text { stable } \\
\text { thereafter }\end{array}$ & $\begin{array}{l}13 \% \text { increase } \\
\text { by decade up to } \\
70 \text { y, then } 9 \% \\
\text { decrease by } \\
\text { decade }\end{array}$ & $\begin{array}{l}6 \% \text { increase by } \\
\text { decade until } 70 \\
y, \quad \text { stable } \\
\text { thereafter }\end{array}$ \\
\hline 39 & $\begin{array}{l}6501 \text { women aged } 65-80, \\
\sim 15 \text { years follow-up }\end{array}$ & RBC & $\begin{array}{l}\text { RBC Omega-3 Index increases } \\
\text { with age: }\end{array}$ & $\begin{array}{l}\text { Higher Omega- } \\
3 \quad \text { index } \\
\text { quartile: } 0.6 \mathrm{y} \\
\text { older } \\
\begin{array}{l}\text { compared to } \\
\text { lower quartile }\end{array}\end{array}$ & & \\
\hline 48 & $\begin{array}{l}\mathrm{n}=456,320 \text { men and } 136 \\
\text { women, } 18 \text { to } 70 \text { y }(\sim 42.5 \\
\text { y) }\end{array}$ & RBC-PL & $\begin{array}{l}\text { EPA+DHA: } 1.4 \text { fold increase in } \\
\text { both gender between } 18-20 \text { vs } \\
60+\text { years }\end{array}$ & & & \\
\hline 141 & $\begin{array}{l}411 \text { Japaneses (194 men } \\
\text { and } 217 \text { women), } 418 \\
\text { Koreans (240 men and } \\
178 \text { women) and } 252 \\
\text { Mongolians (100 men and } \\
152 \text { women) aged } 30-60 \mathrm{y}\end{array}$ & Plasma & $\begin{array}{l}\text { EPA and DHA increase with age } \\
\text { in Japanese and Koreans. }\end{array}$ & & $\begin{array}{l}\text { Japaneses: } 1.4 \\
\text { fold increase } \\
\text { Koreans: } 1.9 \\
\text { fold increase }\end{array}$ & $\begin{array}{l}\text { Japaneses: } 1.2 \\
\text { fold increase } \\
\text { Koreans: } 1.3 \text { fold } \\
\text { increase } \\
\text { Mongolians: } 1.1 \\
\text { fold decrease }\end{array}$ \\
\hline 58 & $\begin{array}{l}75 \text { adults admitted for } \\
\text { elective surgery: } 48 \text { men } \\
(\sim 58 \text { y: } 27-81 \text { y) and } 27 \\
\text { women }(\sim 58 \text { y: } 33-74 \text { y) }\end{array}$ & $\begin{array}{l}\text { Plasma PL, RBC-PL and } \\
\text { AT }\end{array}$ & $\begin{array}{l}\text { Positive correlation between } \\
\text { EPA+DHA and age, in plasma } \\
\text { and RBC-PL but not in AT }\end{array}$ & & & \\
\hline 42 & $\begin{array}{l}163 \text { adults, } 74 \text { men and } 89 \\
\text { women, } 20 \text { to } 80 \text { years }\end{array}$ & RBC & $\begin{array}{l}\text { Omega-3 Index increased each } \\
\text { decade but decreased by } 0.3 \\
\text { units with each } 3 \text {-unit increase } \\
\text { in BMI }\end{array}$ & $\begin{array}{l}0.5 \quad \text { unit } \\
\text { increase by } 10 \\
\text { years of age }\end{array}$ & & \\
\hline 142 & $\begin{array}{l}119 \text { subjects for each } \\
\text { population, Icelandic (59 } \\
\text { males and } 60 \text { females) } \\
\text { and Icelandic-Canadians }\end{array}$ & Plasma PL & $\begin{array}{l}\text { Young Icelandic-Canadians had } \\
\text { lower levels of EPA than the } \\
\text { middle and oldest age groups }\end{array}$ & & $\begin{array}{l}1.8 \text { fold } \\
\text { increase in } \\
\text { oldest group } \\
\text { compared to } \\
\text { the youngest }\end{array}$ & \\
\hline
\end{tabular}




\begin{tabular}{|c|c|c|c|c|c|}
\hline & $\begin{array}{l}(60 \text { males and } 59 \\
\text { females), } 20-69 \text { years }\end{array}$ & & & & \\
\hline 143 & $\begin{array}{l}54 \text { women, } 43-60 \text { years: } \\
19 \text { premenopausal ( } 48 \\
\text { y), } 16 \text { postmenopausal } \\
\text { not receiving HRT ( } 52 \text { y) } \\
\text { and } 19 \text { postmenopausal } \\
\text { receiving HRT }(\sim 51 \mathrm{y})\end{array}$ & Serum PL & $\begin{array}{l}\text { DHA levels were significantly } \\
\text { lower in premenopausal } \\
\text { women than postmenopausal } \\
\text { women. Those receiving HRT } \\
\text { had significantly lower levels of } \\
\text { DPA. }\end{array}$ & & $\begin{array}{l}1.3 \text { fold increase } \\
\text { in } \\
\text { postmenopausal } \\
\text { women without } \\
\text { HRT vs } \\
\text { premenopausal }\end{array}$ \\
\hline 144 & $\begin{array}{l}338 \quad \text { women; alcohol } \\
\text { intake: abstainers }(n=254 \text {, } \\
\sim 24,2 \quad y), \quad \text { occasional } \\
(n=45, \sim 27,9 \quad \text { y) and } \\
\text { habitual }(n=8, \sim 30,5 \text { y) }\end{array}$ & Plasma and RBC & $\begin{array}{l}\text { DHA and AA correlates } \\
\text { positively with maternal age }\end{array}$ & & $\begin{array}{l}\uparrow \text { in plasma } \\
(\mu \mathrm{g} / \mathrm{ml} \text { et \%) } \\
\uparrow \text { in } \mathrm{RBC}(\%)\end{array}$ \\
\hline 49 & $\begin{array}{l}99 \text { Icelandic women, } 18 \text { to } \\
73 \text { y }(\sim 45.8 \text { y) }\end{array}$ & RBC & $\begin{array}{l}\text { Proportions of total n-3 PUFA, } \\
\text { EPA, and DHA correlated } \\
\text { positively with age }\end{array}$ & $\uparrow$ & $\uparrow$ \\
\hline 145 & $\begin{array}{l}200 \text { Japaneses, } 126 \text { males } \\
\text { and } 74 \text { females, } \sim 50 \text { y } \\
(<35 \text { to } \geq 65 y)\end{array}$ & $\begin{array}{l}\text { Serum and RBC total } \\
\text { lipids }\end{array}$ & $\begin{array}{l}\text { EPA, DHA, n-3: n-6 ratio and } \\
\text { EPA: AA ratio increased with } \\
\text { age (stronger effect in serum): }\end{array}$ & $\begin{array}{l}\text { Group } \geq 65 \text { y } \\
\text { compared to } \\
\text { group }<35 \mathrm{y}: 2.3 \\
\text { fold increase in } \\
\text { serum and } 2 \\
\text { fold increase in } \\
\text { RBC }\end{array}$ & $\begin{array}{l}\text { Group } \geq 65 \text { y } \\
\text { compared to } \\
\text { group }<35 \text { y: } 1.7 \\
\text { fold increase in } \\
\text { serum and } 1,2 \\
\text { fold increase in } \\
\text { RBC }\end{array}$ \\
\hline
\end{tabular}

AA: arachidonic acid, EPA: eicosapentaenoic acid: DHA, docosahexaenoic acid: DPA: docosapentaenoic acid, AT: adipose tissue, PUFA: polyunsaturated fatty acids, FA, fatty acids, PC: phosphatidylcholine, PE: phosphatidylethanolamine, PS: phosphatidylserine, CE: cholesteryl esters, NEFA: non-esterified fatty acids, RBC: red blood cells, HRT: Hormone receiving therapy, BMI: body mass index, 
Table 2: Blood fatty acid modulation by age after an omega-3 fatty acid supplementation

\begin{tabular}{|c|c|c|c|c|}
\hline Reference & $n$, sex and age & Blood pool & $\begin{array}{l}\text { Omega-3 } \\
\text { supplementation }\end{array}$ & Age effects \\
\hline 59 & $\begin{array}{l}n=115,60 \text { men and } 55 \\
\text { women, } 20 \text { to } 45 \text { years }\end{array}$ & RBC & $\begin{array}{l}5 \text { doses }(0,300,600,900, \\
1800 \mathrm{mg}) \text { of EPA+DHA } \\
\text { (fish oil) for } \sim 5 \text { months }\end{array}$ & $\begin{array}{l}\text { Lower Omega- } 3 \text { Index }(\mathrm{O} 3 \mathrm{I}) \text { status }(\mathrm{P}<0.0001) \text { and } \\
\text { older age }(\mathrm{P}=0.02) \text { each predicted greater increases in } \\
\text { O3I with supplementation }\end{array}$ \\
\hline 62 & $\begin{array}{l}24-28 \text { participants in each } \\
\text { age group (except as noted } \\
\text { in the tables), young adult } \\
=18-34 \text { y }(\sim 23 \text { y) and } \\
\text { elderly group }=\geq 65 \text { y }(\sim 74 \\
\text { y) }\end{array}$ & Plasma & $\begin{array}{l}\text { Two supplementations: } n- \\
3 \text { supplement enriched in } \\
\text { DHA ( } 680 \mathrm{mg} \text { DHA/d plus } \\
323 \mathrm{mg} \text { EPA/d) for } 3 \\
\text { weeks, or a supplement } \\
\text { enriched in EPA ( } 1480 \mathrm{mg} \\
\text { EPA/d plus } 250 \mathrm{mg} \\
\text { DHA/d) for } 6 \text { weeks }\end{array}$ & $\begin{array}{l}\text { Expressed as } \% \text { of total fatty acids: At baseline, total n- } \\
3 \text { PUFA, EPA and DPA higher in elderly ( } 32 \%, 100 \% \text { and } \\
25 \% \text { respectively); Expressed as concentration (mg/L): } \\
\text { At baseline, total n-3 PUFA, 18:3n-3, DHA, DPA and } \\
\text { EPA higher in elderly ( } 74 \%, 40 \%, 63 \%, 85 \% \text { and } 142 \% \\
\text { respectively); After supplementation: no higher effect } \\
\text { with increasing age }\end{array}$ \\
\hline 63 & $\begin{array}{l}15 \text { young }(22-35 \text { y) and } 10 \\
\text { older ( } 51-71 \text { y) women }\end{array}$ & Plasma & $\begin{array}{l}\text { Daily } 1680 \mathrm{mg} \text { EPA and } \\
720 \mathrm{mg} \text { DHA for } 3 \text { months }\end{array}$ & $\begin{array}{l}\text { Older women had a significantly higher increase in EPA } \\
\text { and DHA than did young women (EPA: } 10 \text {-fold vs } 8 \text {-fold } \\
\text { and DHA: } 2.5 \text {-fold vs } 2 \text {-fold) }\end{array}$ \\
\hline 64 & $\begin{array}{l}6 \text { young }(23-33 \text { y) and } 6 \\
\text { older }(51-68 \text { y) women }\end{array}$ & Plasma & $\begin{array}{l}\text { Daily } 1680 \mathrm{mg} \text { EPA and } \\
720 \mathrm{mg} \text { DHA for } 3 \text { months }\end{array}$ & $\begin{array}{l}\text { At baseline there was no difference in percentage of } \\
\text { EPA and DHA between young and older women; } \\
\text { however, after } 3 \text { mo of ( } \mathrm{n}-3) \text { fatty acid } \\
\text { supplementation, older women had a significantly } \\
\text { higher percentage of EPA and DHA: EPA: 10-fold vs 5- } \\
\text { fold and DHA: } 2.5 \text {-fold vs } 1.6 \text {-fold }\end{array}$ \\
\hline 65 & $\begin{array}{l}10 \text { young }(5 \text { men and } 5 \\
\text { women, } \sim 22 \text { y) and } 10 \\
\text { elderly }(5 \text { men and } 5 \\
\text { women, } \sim 75 \text { y) }\end{array}$ & Plasma & $\begin{array}{l}\text { EPA-enriched supplement } \\
(1.4 \mathrm{~g} / \mathrm{d} \text { of EPA and } 0.2 \mathrm{~g} / \mathrm{d} \\
\text { of DHA }) \text { for } 6 \mathrm{wk}\end{array}$ & $\begin{array}{l}\text { Before and after the EPA supplement, fasting plasma } \\
\text { EPA was higher in the elderly (by } 85 \% \text { and } 67 \% \\
\text { respectively) }\end{array}$ \\
\hline
\end{tabular}




\begin{tabular}{|c|c|c|c|c|}
\hline 66 & $\begin{array}{l}\text { Young (18-42 y; } n=93) \text { and } \\
\text { old ( } 53-70 y ; n=62) \text { men }\end{array}$ & Plasma and MNC PL & $\begin{array}{l}\text { Placebo (corn oil) or } 1.35 \\
2.7 \text {, or } 4.05 \text { g EPA/day for } \\
12 \text { wks }\end{array}$ & $\begin{array}{l}\text { In both plasma and MNC PL : at baseline, EPA and DPA } \\
\text { increase with age while after supplementation, only } \\
\text { EPA increases in old men; at baseline, EPA, DPA and } \\
\text { DHA respectively } \sim 1.3, \sim 1.1 \text { and } \sim 1.4 \text { higher in older in } \\
\text { plasma and EPA and DHA respectively } \sim 1.3 \text { and } \sim 1.25 \\
\text { higher in older in MNC; with High-EPA } \\
\text { supplementation: EPA and DPA respectively } \sim 1.6 \text { and } \\
\sim 1.3 \text { higher in plasma and EPA } \sim 1.4 \text { higher in MNC }\end{array}$ \\
\hline 61 & $\begin{array}{l}\text { Elderly }(n=9,5 \text { males and } 4 \\
\text { females, } 74 \text { y) and young } \\
(n=10,5 \text { males and } 5 \\
\text { females, } 24 \text { y) }\end{array}$ & Plasma & $\begin{array}{l}680 \mathrm{mg} / \text { day of DHA and } \\
320 \mathrm{mg} / \text { day of EPA for } 3 \\
\text { weeks, followed by } 2 \\
\text { weeks of wash-out }\end{array}$ & $\begin{array}{l}\text { Higher baseline plasma EPA in elderly group; In } \\
\text { response to the supplement, plasma DHA rose } 42 \% \\
\text { more in the elderly but EPA responded similarly in } \\
\text { both groups }\end{array}$ \\
\hline 67 & $\begin{array}{l}\mathrm{n}=193 \text { (101 women, } 92 \\
\text { men), 20-79 y }\end{array}$ & $\begin{array}{l}\text { Plasma PC, CE, NEFA } \\
\text { and TG; MNC; RBC; } \\
\text { PLAT; BU; AT }\end{array}$ & $\begin{array}{l}\text { EPA+DHA equivalent to } 0, \\
1,2 \text { or } 4 \text { portions of oily } \\
\text { fish per week, for } 12 \\
\text { months }\end{array}$ & $\begin{array}{l}\text { At baseline, EPA in AT and DHA in plasma TG and AT } \\
\text { higher with increasing age; Following } \\
\text { supplementation, EPA in plasma TAG higher with } \\
\text { increasing age while DHA in AT smaller with increasing } \\
\text { age }\end{array}$ \\
\hline 60 & $\begin{array}{l}92 \text { Danish women: half } \\
\text { premenopaused }(\sim 43 \quad \text { y) } \\
\text { and half postmenopaused } \\
(\sim 56 \text { y), } 18-70 y\end{array}$ & PLAT, AT & $\begin{array}{l}2,2 \text { g of marine } n-3 \text { PUFA } \\
(38,5 \% \\
\text { EPA, } 25,9 \% \text { DHA and } 6,0 \% \\
\text { DPA) or control oil (thistle } \\
\text { oil) daily for } 12 \text { weeks }\end{array}$ & $\begin{array}{l}\text { Baseline contents of EPA, DPA and DHA were all } \\
\text { significantly lower }(P<0.05) \text { in premenopausal group } \\
\text { both in platelets and adipose tissue, except for EPA in } \\
\text { platelets }(\mathrm{P}=0.05) \text {; After supplementation, increase in } \\
\text { platelets and adipose tissue was, however, the same } \\
\text { in both groups }\end{array}$ \\
\hline
\end{tabular}

